\title{
The cell wall in plant cell response to trace metals: polysaccharide remodeling and its role in defense strategy
}

\author{
Magdalena Krzesłowska
}

Received: 11 November 2009/Revised: 22 July 2010/Accepted: 23 July 2010/Published online: 15 August 2010

(C) The Author(s) 2010. This article is published with open access at Springerlink.com

\begin{abstract}
This review paper is focused predominantly on the role of the cell wall in the defense response of plants to trace metals. It is generally known that this compartment accumulates toxic divalent and trivalent metal cations both during their uptake by the cell from the environment and at the final stage of their sequestration from the protoplast. However, from results obtained in recent years, our understanding of the role played by the cell wall in plant defense response to toxic metals has markedly altered. It has been shown that this compartment may function not only as a sink for toxic trace metal accumulation, but that it is also actively modified under trace metal stress. These modifications lead to an increase in the capacity of the cell wall to accumulate trace metals and a decrease of its permeability for trace metal migration into the protoplast. One of the most striking alterations is the enhancement of the level of low-methylesterified pectins: the polysaccharides able to bind divalent and trivalent metal ions. This review paper will present the most recent results, especially those that are concerned with polysaccharide level, composition and distribution under trace metal stress, and describe in detail the polysaccharides responsible for metal binding and immobilization in different groups of plants (algae and higher plants). The review also contains information related to the entry pathways of trace metals into the cell wall and their detection methods.
\end{abstract}

Communicated by A. K. Kononowicz.

M. Krzesłowska ( $\square)$

Laboratory of General Botany, Faculty of Biology,

Adam Mickiewicz University, Umultowska 89,

61-614 Poznan, Poland

e-mail: magdak@amu.edu.pl
Keywords Heavy metal $\cdot$ Cell wall $\cdot$ Pectin $\cdot \mathrm{Pb}$. Tip growth - Alginate

$\begin{array}{ll}\text { Abbreviations } \\ \text { CW } & \text { Cell wall } \\ \text { ER } & \text { Endoplasmic reticulum } \\ \text { GA } & \text { Golgi apparatus } \\ \text { HMA } & \text { Heavy metal-transporting P-type ATPase } \\ \text { HGA } & \text { Homogalacturonan } \\ \text { mAb } & \text { Monoclonal antibody } \\ \text { PM } & \text { Plasma membrane } \\ \text { PVC } & \text { Prevacuolar compartment } \\ \text { TM } & \text { Trace metal } \\ \text { TGN } & \text { trans-Golgi network. } \\ \text { V } & \text { Vacuole } \\ \text { Vs } & \text { Vesicle }\end{array}$

\section{Introduction}

Trace metal (TM) pollution has become an increasingly serious environmental problem over recent decades due to its toxicity and the susceptibility of the environment. It has led to many detrimental effects in living organisms, from plants and animals to humans. TMs are categorized into those that are essential for many physiological processes, e.g., $\mathrm{Cu}, \mathrm{Zn}$ and $\mathrm{Fe}$, the excess as well as deficiency of which can cause harmful effects in plant cells, and nonessential ones, such as $\mathrm{Pb}, \mathrm{Cd}, \mathrm{Al}$ and $\mathrm{Hg}$, which may be toxic even in relatively low concentrations (for review, e.g., Hall 2002; Patra et al. 2004; Appenroth 2010). Trace metals can enter the plant cell by diffusion through the plasma membrane (PM) (Krzesłowska et al. 2009b), 
via endocytosis (e.g., Malone et al. 1974; Woźny et al. 1982; Książek et al. 1984; Hubner et al. 1985; Krzesłowska and Woźny 1996; Illéš et al. 2006; Wierzbicka et al. 2007; Krzesłowska et al. 2009a; Meyers et al. 2009), and due to the activity of special metal transporters that function in the PM. The latter aspect has been the subject of a great deal of attention and many review papers are available (e.g., Colangelo and Guerinot 2006; Krämer et al. 2007; Krzesłowska et al. 2009b; Pilon et al. 2009; Puig and Penarrubia 2009).

The excess of TMs in plant cells can cause a range of toxic alterations, e.g., the generation of reactive oxygen species (ROS) resulting in oxidative stress (RucińskaSobkowiak and Pukacki 2006; Przymusiński et al. 2007), which leads to the destruction of cell membranes: the PM, the endomembrane system and membranous organelles, in particular chloroplast, mitochondrion (Hall 2002; Patra et al. 2004) and nucleus (Prasad 2004; Glińska et al. 2007). Furthermore, trace metals, especially non-essential ones, can destroy enzyme functioning by entering in place of proper ions for building their molecules or by binding to their sulfhydryl and carboxyl groups, thereby changing their conformation (Hall 2002; Patra et al. 2004). Moreover, they destroy nucleic acid conformation (Pawlak and Deckert 2007), alter the water balance and disturb many other plant cell functions (Hall 2002; Patra et al. 2004). All these alterations can lead to plant growth inhibition, necrosis and finally to the death of the whole plant (Prasad 2004). It is worth noting, however, that a low dosage of a stress factor can cause a hormesis effect, i.e., the better functioning of the plant organisms under low TMs dosage (Schwarzerová et al. 2002).

Plants cannot avoid stress conditions by escaping from contaminated areas. Therefore, they have developed a range of resistance mechanisms, which enable them to avoid and/or tolerate stress factors and survive even in highly contaminated soils and waters (Levitt 1980). Defense strategies can be divided into avoidance and tolerance types. Avoidance includes all mechanisms, which protect the plant cell from TMs entering the protoplast. Tolerance concerns those mechanisms that enable the plant to: (1) neutralize toxic metals inside the cell, (2) remove them from the protoplasts (e.g., to the apoplast) and (3) neutralize their toxic effects (Levitt 1980). Thus, outside the protoplast TMs are: accumulated by mycorrhizal fungi (for review, e.g., Schützendübel and Polle 2002), chelated within the rhizosphere, bound by the CW compounds and blocked in their migration by the callose layer. Inside the cell, TMs are, e.g., chelated by metallothioneins, phytochelatins, organic acids and other compounds, and sequestered within the vacuole $(\mathrm{V})$. One of the main strategies of plant cells for coping with TMs is to remove them from the cytoplasm by sequestration in extracytoplasmic compartments such as the $\mathrm{CW}$ and the $\mathrm{V}$. It protects the most sensitive sites within the protoplast from TM's toxicity (e.g., Vollenweider et al. 2006; Kopittke et al. 2007, 2008; Poschenrieder et al. 2008; Krzesłowska et al. 2009a, 2010; Meyers et al. 2009).

The aim of this review is to show an important role that the $\mathrm{CW}$ plays in the defensive response of plants to TM stress. Other resistance mechanisms have been extensively discussed in other review papers and therefore are only mentioned here. The most recent results pertaining to $\mathrm{CW}$ remodeling under TM stress, in particular observations involving polysaccharide amount, composition and distribution, and its possible consequences for plant adaptation to enhanced levels of TMs in the soil are described. Moreover, the common features of the CWs that are responsible for metal binding and immobilization of different groups of plants (algae and higher plants) are outlined.

\section{Common features of plant cell walls that enable them to bind trace metals}

Plant CWs are rich in compounds, which are able to bind divalent and trivalent metal cations. Polysaccharides play a crucial role in TM binding and accumulation in the CW, although other compounds such as proteins, amino acids and phenolics also take part in this process. The ability to bind divalent metal cations depends on the number of functional groups such as $-\mathrm{COOH},-\mathrm{OH}$ and $-\mathrm{SH}$ occurring in $\mathrm{CW}$ compounds (Dronnet et al. 1996; Kartel et al. 1999; Davis et al. 2003; Pelloux et al. 2007). However, the essential capacity of the $\mathrm{CW}$ for binding divalent and trivalent metal cations depends mainly on the amount of polysaccharides abundant in carboxyl groups. There are alginates in algae (Davis et al. 2003) and homogalacturonans (HGA) in higher plants, both Bryophytes (Tyler 1990) and vascular plants (Dronnet et al. 1996; Kartel et al. 1999; Fritz 2007; Pelloux et al. 2007; Caffall and Mohnen 2009).

Pectins are very complex and consist of four major polysaccharide domains: HGA, rhamnogalacturonan I (RGI), rhamnogalacturonan II (RGII) and xylogalacturonan (XGA). The domains differ in both the structure of the macromolecule backbone and the presence and diversity of side chains (for review, e.g., Willats et al. 2006; Pelloux et al. 2007; Caffall and Mohnen 2009). Pectins occur in all cells and typically constitute about $30 \%$ of type I primary walls occurring in dicotyledons. Secondary walls and type II primary walls, characteristic mainly of grasses, normally have a much lower content of pectins (Pelloux et al. 2007; Caffall and Mohnen 2009). The main pectin domain responsible for binding divalent and trivalent metal cations is HGA (Dronnet et al. 1996). It is synthesized in the Golgi apparatus (GA) and transported by a secretion pathway into the CW (Levy and 
Fig. 1 Cross-linking (egg-box structure) between polymers a of low-methylesterified pectins present in the $\mathrm{CW}$ of higher plants (Caffall and Mohnen 2009 modified) and b of alginic acid present in the $\mathrm{CW}$ of brown algae, in uncontaminated conditions with $\mathrm{Ca}^{2+}$ ions and in presence of $\mathrm{Pb}^{2+} ; G \alpha-\mathrm{L}$ glucuronic acid residue, $M$ 1,4-linked $\beta$ D mannuronic acid residue (Lozanno-Álvarez et al. 2009 modified) (a)

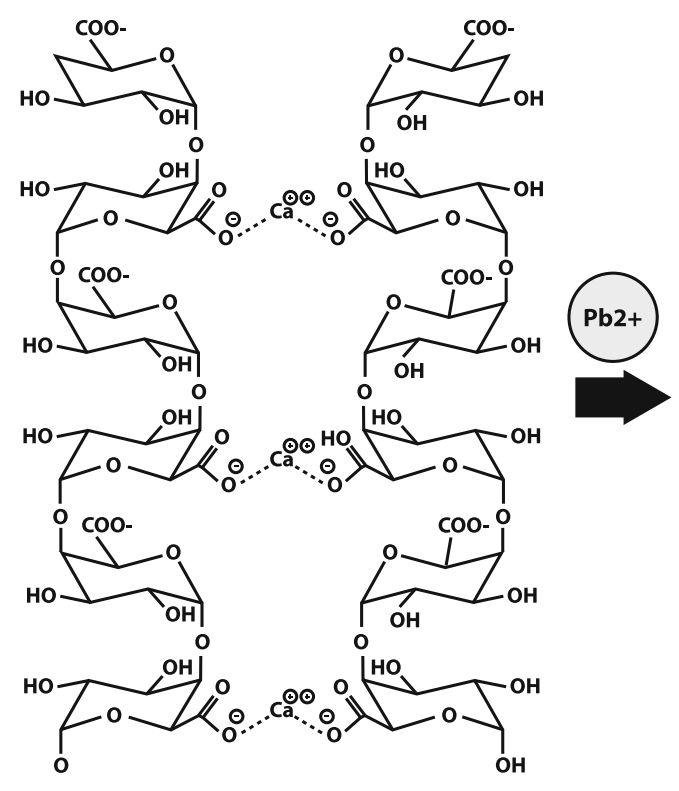

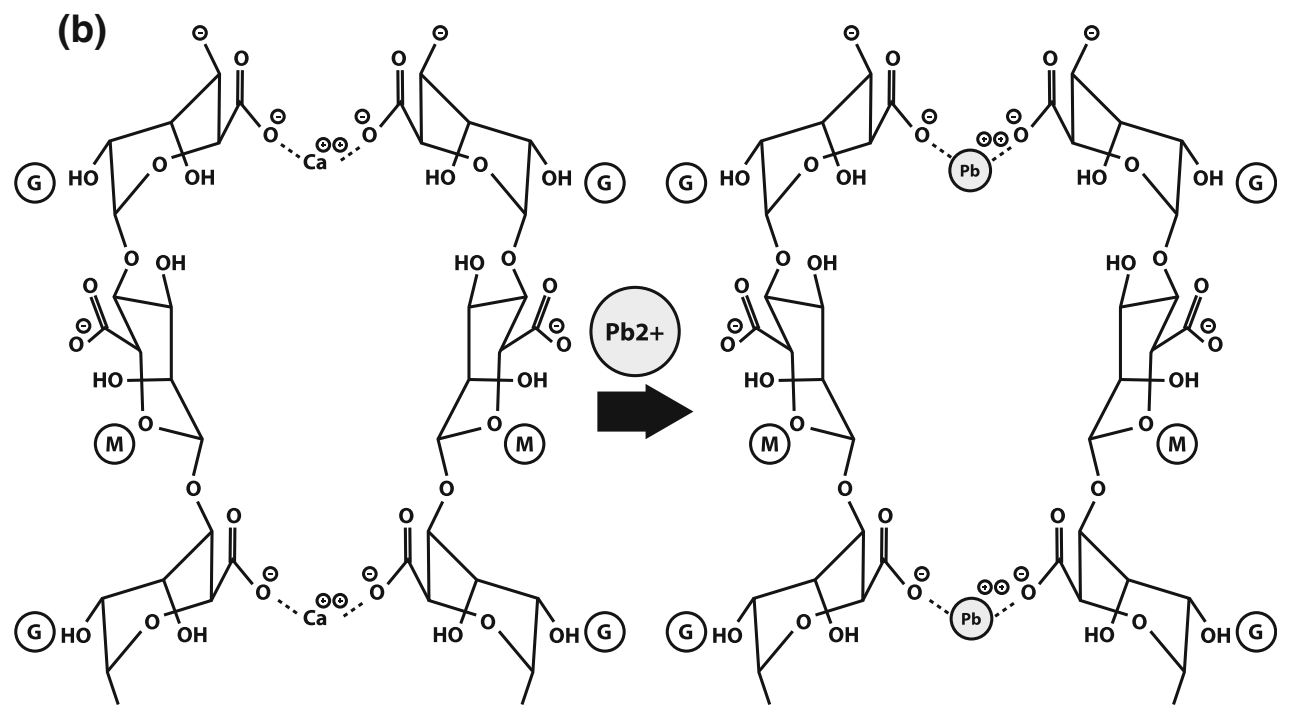

Staehelin 1992; Willats et al. 2006). In the GA, the HGA backbone is substituted by methyl groups $\left(\mathrm{CH}_{3}\right)$. This methylesterified fraction of HGA shows at least $80 \%$ esterification (Willats et al. 2006). Within the CW, highly methylesterified HGA is mainly modified by two enzymes: pectinmethylestrase (PME) responsible for demethylation of HGA, and pectin acetylase, responsible for modifications of its acetylation degree. Demethylation of HGA leads to the formation of a few fractions with different degrees of methylesterification. These HGA fractions can be recognized by monoclonal antibodies (mAb; for review, e.g., Willats et al. 2006): low-methylesterified HGA (lower than $40 \%$ ) by JIM5, HGA with a non-blockwise pattern of deesterification (esterification not higher than 20\%) by LM7, and HGA with ca. 30 non-methylesterified GalA residues (blockwise) by PAM1. Highly methylesterified HGA (esterification not lower than $80 \%$ ) is recognized by JIM7.

Homogalacturonan fractions, in particular those with a low degree of methylesterification, containing some amounts of free carboxyl groups, are able to bind divalent and trivalent metal ions (Dronnet et al. 1996; Kartel et al. 1999; Fritz 2007).

It has been shown that low-methylesterified HGA can interact through calcium bridging between two free carboxyl groups (Fig. 1; Grant et al. 1973). They then form a so-called egg-box structure (Fig. 1; Grant et al. 1973). This results in calcium gel formation and CW stiffening (for review, e.g., Carpita and Gibeaut 1993; Caffall and Mohnen 2009). Binding studies with low-methylesterified pectins have shown that the affinity of divalent and trivalent 
metal cations depends on the origins of the pectin and could be as follows: $\mathrm{Al}^{3+}>\mathrm{Cu}^{2+}>\mathrm{Pb}^{2+}>\mathrm{Zn}^{2+}=\mathrm{Ca}^{2+}$ or $\mathrm{Cu}^{2+}=\mathrm{Pb}^{2+}>\mathrm{Cd}^{2+}=\mathrm{Zn}^{2+}>\mathrm{Ca}^{2+}$ (Dronnet et al. 1996) or $\mathrm{Pb}^{2+}>\mathrm{Cu}^{2+}>\mathrm{Co}^{2+}>\mathrm{Ni}^{2+}>\mathrm{Zn}^{2+}>\mathrm{Cd}^{2+}$ (Ernst et al. 1992; Kartel et al. 1999; Fritz 2007). It clearly shows that among bivalent metal cations, $\mathrm{Cu}^{2+}$ and $\mathrm{Pb}^{2+}$ are most strongly bound to pectins and $\mathrm{Zn}^{2+}, \mathrm{Ni}^{2+}$ and $\mathrm{Ca}^{2+}$ are much less strongly bound. Thus, calcium ions can be replaced in these connections by trivalent $\mathrm{Al}^{3+}$ and also by such divalent TM cations as $\mathrm{Pb}^{2+}, \mathrm{Cu}^{2+}, \mathrm{Cd}^{2+}$ and $\mathrm{Zn}^{2+}$ (Fig. 1; Dronnet et al. 1996). The orders explain, moreover, why the amount of $\mathrm{Al}$ in the $\mathrm{CWs}$ remains uninfluenced by the addition of other TMs (Brunner et al. 2008).

The interaction between divalent or trivalent metal cations and pectin is complex and depends on (1) charge density of the pectin, (2) ionic strength of the solution and (3) strength of the interaction between the cation and pectin (Renard and Jarvis 1999). Methylation, as also acetylation, of pectins decreases their affinity to TMs. However, it is worth noting that acetylated HGA can bind to $\mathrm{Pb}^{2+}$ and $\mathrm{Cd}^{2+}$, as shown recently in Arabidopsis thaliana (PołećPawlak et al. 2007).

Alginate occurs in the $\mathrm{CW}$ of all brown algae. The highest amount has been found in Sargassum spp. (Davis et al. 2003). It may constitute $10-45 \%$ of their dry mass, e.g., in Sargassum longifolium about 17\% (Chapman 1980), while in Sargassum fluitans about 45\% (Fourest and Volesky 1996). Alginates are polysaccharides that consist of two kinds of residues: D-mannuronic acid and L-guluronic acid linked via $\beta(1 \rightarrow 4)$ glycosidic bonds, forming a non-regular blockwise order along the chain. Trace metals show a higher affinity for alginic acids containing more $\alpha$-L-guluronic acid (Davis et al. 2003). The rod-like shape of the polyL-glucuronic sections results in an alignment of two chain sections, which enables interaction with divalent cations. Divalent metal ions are lined with the carboxylate and other oxygen atoms of glucuronic acid residues (Fig. 1). This description is known as the "egg-box" structure (Davis et al. 2003). It is similar to the egg-box structure formed by low-methylesterified $\mathrm{HGA}$ in the $\mathrm{CW}$ of higher plants (Fig. 1; Grant et al. 1973; Pelloux et al. 2007).

To sum up, the binding of divalent and trivalent metal cations both to HGA in CW of higher plants and alginate in brown algae $\mathrm{CW}$ is based mainly on the ion exchange mechanism and involves the formation of the egg-box structure, where two alginate chains or HGA interact by a divalent or a trivalent metal cation (Fig. 1). In uncontaminated conditions, the metal that takes part in the interaction between two alginates or HGA macromolecules is calcium. However, in the presence of other divalent metal cations, in particular $\mathrm{Pb}, \mathrm{Cu}, \mathrm{Zn}, \mathrm{Cd}$ or trivalent $\mathrm{Al}$, which shows a higher affinity both to alginate and HGA than $\mathrm{Ca}^{2+}$, this cation is replaced in this interaction by these metals (Fig. 1).

\section{Deposition of TMs in the plant $\mathrm{CW}$ and its role in plant cell defense response}

Detection of TMs in plant cell wall

The presence of TMs in the CW can be detected by a range of methods. Lead can be identified by optical microscopy, e.g., by rhodizonic acid that forms red complexes with this metal (Tung and Temple 1996). Cadmium may be identified, e.g., by Leadmium reagent (Xiong et al. 2009) in fluorescence and confocal microscopy. Aluminum is often stained with, e.g., morin (unbound, free Al ions; Eticha et al. 2005a) and lumogallion (Silva et al. 2000), the fluorochromes also used for fluorescence and confocal microscopy. Some TMs are clearly recognizable in transmission electron microscopy (TEM) when they form irregular electron-dense deposits. The largest ones are observed for $\mathrm{Pb}$ (Fig. 2b, h, i). This metal can form extremely large crystalline-like deposits (Fig. 2b), varying in size and shape. In many cases, such a deposit needs special accommodation space or thickening of the CW at the site (Fig. 2i; Malone et al. 1974; Wierzbicka 1998; Kopittke et al. 2007, 2008; Meyers et al. 2009; Krzesłowska et al. 2010). Lead can also form smaller deposits varying in size and shape and can occur in various amounts. Sometimes, however, $\mathrm{Pb}$ deposits can completely saturate the CW (Fig. 2a; Wierzbicka 1998). Other TMs such as $\mathrm{Cd}$ and $\mathrm{Zn}$ may also form deposits within the $\mathrm{CW}$, but usually smaller than $\mathrm{Pb}$ deposits (Carrier et al. 2003; Neumann and zur Nieden 2001).

Moreover, the detection of TMs is possible by X-ray microanalysis (Samardakiewicz and Woźny 2000; Neumann and zur Nieden 2001; Carrier et al. 2003; Kopittke et al. 2008; Meyers et al. 2009; Krzesłowska et al. 2010), energy dispersive transmission electron microscopy (Lütz-Meindl 2007) and micro-protoninduced X-ray emission (Vogel-Mikuš et al. 2008). These methods enable detection of TMs when they do not form deposits and are dissolved, e.g., in cytosol. Moreover, they may provide information regarding the chemical form of TM occurrence. Using X-ray microanalysis, it has been shown that $\mathrm{Zn}$ was deposited as silicate in the CW of Minuaria verna (Neumann and zur Nieden 2001), $\mathrm{Pb}$ was recognized in a non-toxic form of chloropyromorphite $\left(\mathrm{Pb}_{5}\left(\mathrm{PO}_{4}\right)_{3} \mathrm{Cl}\right)$ in the $\mathrm{CW}$ of signal grass Brachiaria decumbens (Kopittke et al. 2008) and as phosphohedyphane $\left(\mathrm{Pb}_{3} \mathrm{Ca}_{2}\left(\mathrm{PO}_{4}\right)_{3} \mathrm{Cl}\right)$ in the hyperaccumulating plant Brassica juncea (Meyers et al. 2009). Cadmium was deposited in the $\mathrm{CW}$ in aggregates with phosphate or calcium (Sela et al. 1988). It was found, moreover, that electron-dense deposits detected in root $\mathrm{CW}$ of Vicia faba growing on mine tailings contained $\mathrm{Pb}$, Zn, Ca and C (Probst et al. 2009). 
Fig. 2 Lead deposits (black arrows) and $\mathrm{CW}$ modifications in Funaria hygrometrica and Populus tremula $\mathrm{x}$ tremuloides (poplar) root protonema apical cell exposed to lead. a The example of $\mathrm{CW}$ almost completely saturated with $\mathrm{Pb}$ deposits in root cell of poplar ( $\mathrm{Pb} 32 \mu \mathrm{M}, 24 \mathrm{~h}), \mathbf{b}$ the example of large, crystalline-like $\mathrm{Pb}$ deposits in root $\mathrm{CW}$ of poplar (Pb $32 \mu \mathrm{M}, 24 \mathrm{~h}$ ), c, d $F$. hygrometrica protonema apical cells in scanning electron microscopy, c control $\left(\mathrm{H}_{2} \mathrm{O}\right.$, $48 \mathrm{~h}$ )—no CW thickening at the cell tip, $\mathbf{d}$ exposed to $\mathrm{Pb}$ ( $\mathrm{Pb} 4 \mu \mathrm{M}, 48 \mathrm{~h})-\mathrm{CW}$ thickening (white arrowhead) at the swollen tip, e, f $F$.

hygrometrica protonema apical cells-JIM5-pecins (white arrows) immunocytochemical identification in LSM microscopy, e control—no JIM5 pectins in the tip CW, it occurred in subapical $\mathrm{CW}, \mathbf{f} \mathrm{Pb}$ treated protonemata- $\mathrm{CW}$ thickenings rich in JIM5-pectins at the cell tip, $\mathbf{g}-\mathbf{i}$ Funaria hygrometrica protonema apical cells exposed to lead in TEM, JIM5-pectins and callose identification by immunogold, g $\mathrm{Pb} 4 \mu \mathrm{M}, 48 \mathrm{~h}-\mathrm{CW}$ thickening in TEM rich in JIM5 pectins and $\mathrm{Pb}$ deposits, $\mathbf{h} \mathrm{Pb}$ $1000 \mu \mathrm{M}, 4 \mathrm{~h}$-internalization of $\mathrm{Pb}$ deposits together with JIM5-pectins, i pulse-chase experiment: $\mathrm{Pb} 1000 \mu \mathrm{M}, 4$ and 24 h recovering; Large $\mathrm{Pb}$ deposits in CW with local thickening. Callose (white arrowhead) localized from the $\mathrm{PM}$ site separating $\mathrm{Pb}$ deposits. Bars a $2 \mu \mathrm{m}$, b $500 \mathrm{~nm}, \mathbf{c}-$ f $10 \mu \mathrm{m}, \mathbf{g}-\mathbf{i} 200 \mathrm{~nm}$
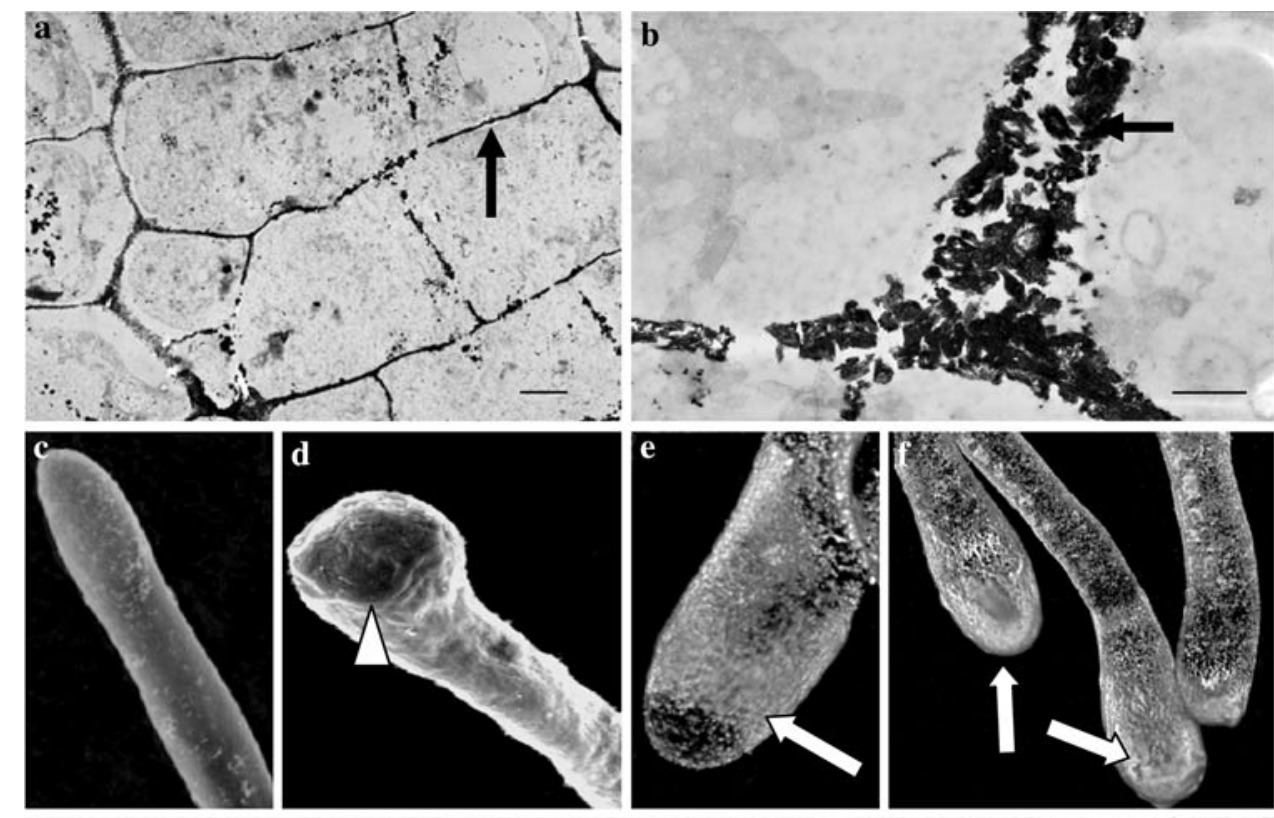

g

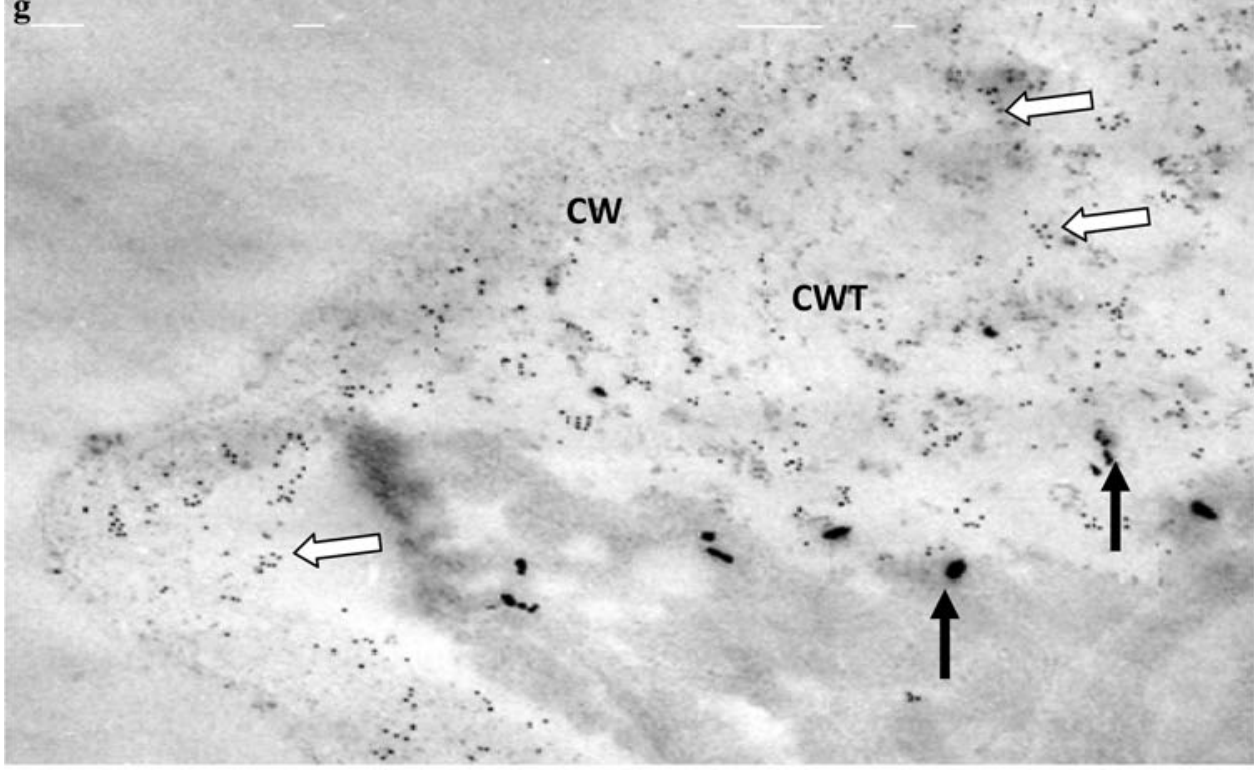

h

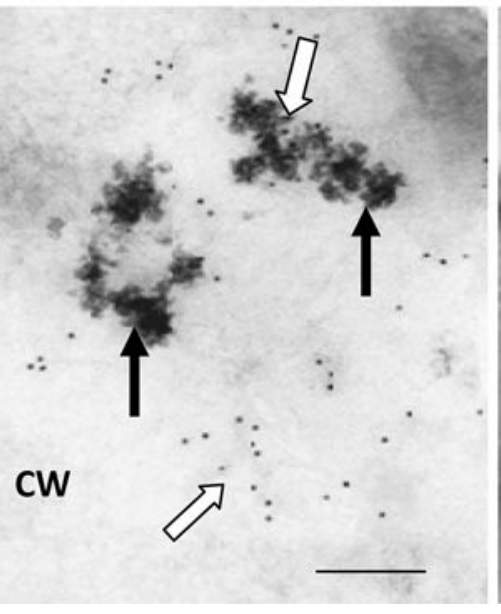

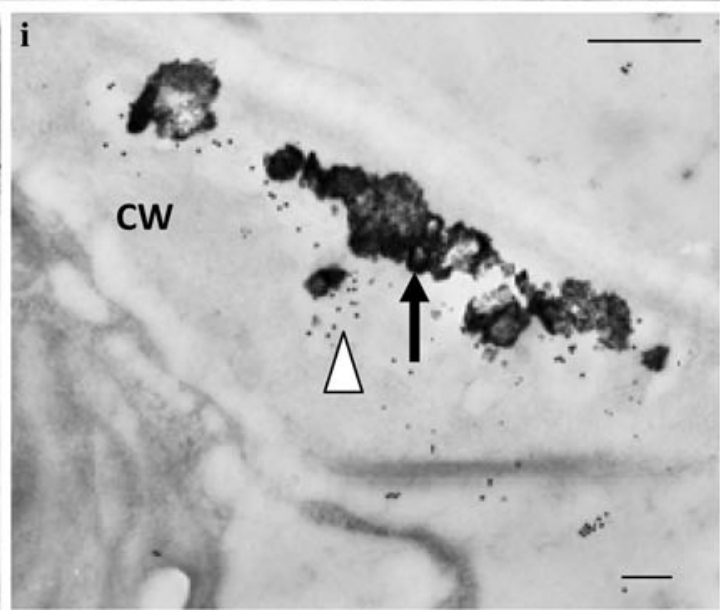


The $\mathrm{CW}$, one of the main compartments

that accumulates trace metals

The occurrence of TMs within the $\mathrm{CW}$ has been reported since the earliest studies of plant cell reactions to TMs (e.g., Malone et al. 1974, Woźny et al. 1982; Wierzbicka 1998; Samardakiewicz and Woźny 2000; Neumann and zur Nieden 2001). Recent papers indicate that the CW is still recognized as one of the main compartments for TM accumulation (e.g., Wójcik et al. 2005; Islam et al. 2007; Małecka et al. 2008; Konno et al. 2010; Meyers et al. 2009) and can contain high amounts of TMs (Kopittke et al. 2007, 2008; Konno et al. 2010; Krzesłowska et al. 2009a, 2010).

The physiological advantage of metal precipitation in the $\mathrm{CW}$ is its strong metabolic inactivation (Jiang and Wang 2008). Until recently, it was believed that TMs bound to $\mathrm{CW}$ compounds, mainly low-methylesterified pectins, are not chemically active, steadily immobilized and do not enter the protoplast. However, new studies have shown that this may not be the case. Some of the CW compounds, including low-methylesterified pectins, can be internalized by endocytosis, in particular in meristematic, dividing cells (Baluška et al. 2002, 2005). Hence, it seems plausible that at least some amounts of the TMs bound to, e.g., low-methylesterified pectins in the $\mathrm{CW}$ can enter the protoplast together with this compound. This hypothesis was tested for the first time and largely verified in Funaria hygrometrica protonemata exposed to $\mathrm{Pb}$. It was detected that in $\mathrm{Pb}$-exposed material the endocytic internalization of pectins markedly increased in comparison to the control. Moreover, in apical cells (able to divide), $\mathrm{Pb}$ deposits bound to low-methylesterified pectins were detected in many of the PM invaginations (Fig. 2h), vesicles, endosomes and vacuoles. This strongly suggested that during internalization of low-methylesterified pectins from the $\mathrm{CW}, \mathrm{Pb}$ bound to this compound entered the cell protoplast endomembrane system as a pectin $+\mathrm{Pb}$ complex (Krzesłowska et al. 2010). On the other hand, the same protonemata cells were found to possess a mechanism, which could protect their protoplast from the return of sequestered $\mathrm{Pb}$. In pulse-chase experiments, all $\mathrm{Pb}$ deposits sequestered within the $\mathrm{CW}$ and $\mathrm{CW}$ thickenings were separated from the PM by a callose layer: a compound which is known to be impermeable to metal ions (Fig. 2i; Hall 2002; Patra et al. 2004). This could protect the cell from sequestered $\mathrm{Pb}$ returning into the protoplast, by endocytosis with CW compounds (Krzesłowska et al. 2010). The results shed a new light on the functioning of the CW in plant cell defense strategy against TMs.

The essential role of plant $\mathrm{CW}$ in defense response against TMs has been supported by the results of studies relating to the defense mechanisms functioning in some hyperaccumulators: plants that are endemic to metalliferous soils and are able to tolerate and accumulate metals to very high concentrations, approximately 100 times more than of a nonaccumulator plant species (Brooks et al. 1977; Milner and Kochian 2008).

It has been found that "copper moss" Scopelophila cataractae, a plant that is able to survive under copperenriched conditions, bound most of the $\mathrm{Cu}$ to the pectin in the CW of protonemata cells. Simultaneously, no growth inhibition of this moss was observed. Thus, it may be concluded that binding $\mathrm{Cu}$ by pectins within the $\mathrm{CW}$ was an effective defense response against this metal and allowed this plant to adapt successfully to $\mathrm{Cu}$-enriched soils (Konno et al. 2010). Furthermore, one of the most common hyperaccumulators, Thlaspi caerulescens, accumulated more than $50 \%$ of TMs in its CW (Salt et al. 1999). Similar results were obtained for Lycopodium japonicum, a fern which grows in $\mathrm{Cu}$-enriched conditions, where $66 \%$ of $\mathrm{Cu}$ was bound in the $\mathrm{CW}$ (Konno et al. 2005). Cell walls were also the preferred compartment for $\mathrm{Cu}$ accumulation in spruce and $\mathrm{Zn}$ accumulation in poplar (Brunner et al. 2008). Furthermore, in the $\mathrm{Ni}$ and $\mathrm{Zn}$ hyperaccumulating plants, more than $60 \%$ of the TMs were localized in the CWs (Yang et al. 2005). A striking example of TM accumulation in the CW may also be found in Phragmites australis, which is considered to be a plant with a high detoxification and phytoremediation potential. Here, $\mathrm{Zn}$ concentrations followed a gradient with the sequence: intercellular space $<\mathrm{CW}<$ vacuole $<$ cytoplasm, indicating that most of the $\mathrm{Zn}$ was accumulated within the apoplast (Jiang and Wang 2008).

As in the case of the essential metals, such as $\mathrm{Cu}$ and $\mathrm{Zn}$, the non-essential ones are accumulated in the $\mathrm{CW}$ of hyperaccumulating plants. For example, $\mathrm{Cd}$ was preferentially accumulated within the $\mathrm{CW}$ of Elodea canadensis, a water plant known for its ability to accumulate high amounts of TMs. This plant exposed to Cd bound 30-70\% of the metal within the CW (Kähkönen et al. 1997; Fritioff and Greger 2003). It was noteworthy that elevated concentrations of $\mathrm{Cd}$ in this plant did not cause higher stress in the cells. The resistance mechanism of E. canadensis to $\mathrm{Cd}$ seems to depend on the removal of metal ions from the protoplast through the PM to the $\mathrm{CW}$ where $\mathrm{Cd}^{2+}$ is bound by the CW compounds (Nyquist and Greger 2007). In addition, the $\mathrm{CW}$ of $E$. canadensis also accumulated other TMs such as $\mathrm{Zn}$ and $\mathrm{Cu}$ in relatively high amounts: 30 and $50 \%$, respectively (Fritioff and Greger 2003).

In other plants, e.g., signal grass (Brachiaria decumbens), non-essential $\mathrm{Pb}$ was initially present in the cytoplasm of rhizodermal and cortical cells and was then sequestered in the CWs (Kopittke et al. 2008). Moreover, recent studies of the spatial distribution of $\mathrm{Al}$ and $\mathrm{Fe}$ within the roots and shoots of Erica andevalensis revealed that 
these elements were predominantly detected in the CWs of epidermal tissues. The authors concluded that sequestration of $\mathrm{Al}$ and $\mathrm{Fe}$ in the extracellular matrix of protective tissues, away from the internal parenchyma, constitutes an important detoxification mechanism (Turnau et al. 2007).

All the examples described above clearly show that the $\mathrm{CW}$ is one of the preferred and essential compartments for TM accumulation, deposition and sequestration. However, the immobilization of TMs in the plant CW is not as stable as previously believed.

How trace metals can enter plant cell wall

Trace metals may enter the CW during the uptake of water solution from the environment (Malone et al. 1974; Hall 2002; Jiang and Wang 2008) and as a result of TM removal from the protoplast during the sequestration process. The latter may include (1) exclusion of TMs due to the activity of special metal transporters present in the PM (for review, Colangelo and Guerinot 2006; Krämer et al. 2007) and (2) removal via vesicular secretion pathway by exocytosis (Fig. 3.; e.g., Malone et al. 1974; Woźny et al. 1982; Książek et al. 1984; Hubner et al. 1985; Krzesłowska and Woźny 1996; Illéš et al. 2006; Wierzbicka et al. 2007; Meyers et al. 2009; Krzesłowska et al. 2010).

The highest number of metal transporters responsible for metal transport outside the protoplast has been characterized in A. thaliana. They are localized in the PM and belong to the group of CPx ATP-ases (ATP-ases containing a conserved intramembranous cysteine-proline/cysteine/ histidine/serine sequence that is thought to play a role in translocation and putative metal-binding domains in the amino or carboxyl terminus, which distinguish them from other P-type ATP-ases (Williams and Mills 2005). Metaltransporting P-type ATPases were named heavy metaltransporting P-type ATPase (HMA) (for review, e.g., Colangelo and Guerinot 2006; Krämer et al. 2007). The following HMAs excluding TMs from the protoplast have so far been identified: AtHMA2 (Eren and Argüello 2004) and AtHMA4 (Mills et al. 2005), responsible for the transport of $\mathrm{Cd}^{2+}$ and $\mathrm{Zn}^{2+}$, AtHMA5 for $\mathrm{Cu}^{2+}$ (AndresColas et al. 2006), AtPDR8 for $\mathrm{Cd}^{2+}$ and $\mathrm{Pb}^{2+}$ (Kim et al. 2007), and AtPDR12 for $\mathrm{Pb}^{2+}$ (Lee et al. 2005). Two such transporters, TgMTPt1 and TgMTPt2, carrying $\mathrm{Co}^{2+}$, $\mathrm{Zn}^{2+}, \mathrm{Ni}^{2+}$ and $\mathrm{Cd}^{2+}$ were localized in the PM of the metal hyperaccumulating plant, Thlaspi goesingense (Kim et al. 2004). Furthermore, it has recently been found that in tobacco (Nicotiana tabacum var. Xanthi), a heterologous expression of AtMRP7 (MRP: the multidrug resistanceassociated protein, ABC transporter) modifies its cadmium accumulation, distribution and tolerance and could be correlated with $\mathrm{Cd}$ removal from cytoplasm and loading to the CW. Hence, metal transporters responsible for transferring TMs from protoplast to apoplast can modify its accumulation and distribution within plant cells. They may also function as a link in the TM transport pathway from plant root to the shoot, and their activity is closely correlated with plant tolerance strategy to TMs (Colangelo and Guerinot 2006; Krämer et al. 2007; Wojas et al. 2009).

Trace metals, in particular $\mathrm{Pb}$, have been commonly detected within the structures of the endomembrane system such as PM invaginations, vesicles (Vs), GA, trans-Golgi network (TGN), the endoplasmic reticulum (ER) and V. Therefore, for many years it has been considered that TMs can enter the protoplast by endocytosis. Hence, TMs, already present within the endomembrane system, can be easily removed from the protoplast by the vesicular secretion pathway and sequestered in the CW (e.g., Malone et al. 1974; Woźny et al. 1982; Książek et al. 1984; Hubner et al. 1985; Krzesłowska and Woźny 1996; Wierzbicka et al. 2007; Meyers et al. 2009). Results of recent studies, concerning the uptake and sequestration of $\mathrm{Al}$ in A. thaliana (Illéš et al. 2006) and $\mathrm{Pb}$ in $F$. hygrometrica (Krzesłowska et al. 2010) have provided more compelling evidence for this phenomenon.

Uptake of Al by endocytosis was identified by using two vital markers: morin, for aluminum (Eggert 1970; Eticha et al. 2005a), and FM4-64, for endosomal/vacuolar membranes (Vida and Emr 1995). It was detected in vivo that $\mathrm{Al}$ was internalized into endosomal/vacuolar compartments in the root meristematic cells and in the cells of the distal portion of the transition zone. In the proximal transition zone where endocytosis did not occur, no uptake of Al was detected. Thus, aluminum was not accumulated in the $\mathrm{V}$ and was localized only in the $\mathrm{CW}$, binding probably during the uptake from the environment (Illéš et al. 2006). Hence, the presence of $\mathrm{Al}$ in the $\mathrm{V}$ was strictly dependent on the endocytic transport pathway.

$\mathrm{Pb}$ endocytosis was detected in an $F$. hygrometrica protonemata apical cell. As described above, the metal was internalized into the endocytic structures together with low-methylesterified pectins, but it could also enter alone. Due to endocytosis, $\mathrm{Pb}$ present in the endomembrane system can be subsequently sequestered in $\mathrm{V}$ and the $\mathrm{CW}$ by the vesicular secretion pathway (Krzesłowska et al. 2010). It was clearly shown in a pulse-chase experiment where almost all $\mathrm{Pb}$, which had been commonly present earlier in the endomembrane system, was removed and finally deposited in the $\mathrm{CW}$ and also in the $\mathrm{V}$. In the $\mathrm{CW}$ it formed large, crystalline-like deposits, which often required a $\mathrm{CW}$ thickening formation to accommodate it (Fig. 2i). In addition, an especially large amount of $\mathrm{Pb}$ was detected in the region of abundance in low-methylesterified pectins at $\mathrm{CW}$ thickenings. They commonly appear under $\mathrm{Pb}$ stress at the cell tip (Krzesłowska et al. 2009a, 2010) where intensive endo- and exocytosis take place in tip growing cells (Ovečka et al. 2005; Zonia and Munnik 2008). 
If TMs can be internalized together with low-methylesterified pectins (Krzesłowska et al. 2010), then it is possible to hypothesize that they may be transported within the protoplast via the brefeldin A (BFA) sensitive pathway: the same route as detected for the transport of this pectin epitope alone (Šamaj et al. 2004). The BFA-dependent pathway of the endomembrane flow is sensitive to brefeldin A, a fungal toxin that allows endocytosis and inhibits secretion and exocytosis. It is contrary to the BFA-independent pathway, which also exists in plant cells (for review, e.g., Otegui and Spitzer 2008). Taking this hypothesis into account, the route of TMs may include the following stages: (1) internalization from the $\mathrm{CW}$ and $\mathrm{PM}$ surface into the TGN/early endosome; (2) transport from the TGN back to the PM and sequestration within the apoplast; (3) or transport to a late endosome/multivesicular body (MVB)/prevacuolar compartment (PVC), which also can play a role as a sorting endosome; (4) from MVB transport back to PM by recycling endosome and, as a result of exocytosis, deposited within the $\mathrm{CW}$; (5) or entering and sequestration in the $\mathrm{V}$ together with the MVB contents (Fig. 3; Otegui and Spitzer 2008; Krzesłowska et al. 2009b).

The pathway of TM removal from the protoplasts and sequestration in the $\mathrm{CW}$ seems to be dependent on its method of entry into the cell. Trace metals that enter due to the activity of the metal transporters located in the PM or by diffusion, and which occur in the cytosol, are predominantly removed by the activity of the other metal transporters present in the PM. Metals present in the endomembrane system, which have entered by endocytosis, are probably largely removed and sequestered in the $\mathrm{CW}$ by the vesicular secretion pathway. However, a cross talk between the two pathways cannot be excluded. For $\mathrm{Cu}$ in A. thaliana it has been detected that metal present in the cytosol could enter the GA-derived compartments, e.g., Vs. Copper, which enters the cytoplasm by the activity of the copper transporters (COPT1, COPT2) localized in the PM, is subsequently chelated in the cytoplasm by the special chaperone (CCH1). The $\mathrm{CCH} 1$ protein brings the copper to a metal transporter RAN1 (responsive to antagonists; Woeste and Kieber 2000; Williams et al. 2000), later called AtHMA7 (Williams and Mills 2005), which may reside in a post-Golgi compartment. RAN1 delivers the copper ion to the ethylene receptors, which then become functional and may be sent ultimately to the PM. Incorporated in the PM, it is responsible for ethylene binding and plays a role in the stress ethylene signaling pathway (Woeste and Kieber 2000).

Moreover, two other transporters, AtECA3 (Mills et al. 2005) and MTP11 (Delhaize et al. 2007), which carry
Fig. 3 The possible pathways of TM entering the cell, transport within the protoplasts and exclusion: a summarized scheme (Otegui and Spitzer 2008 modified)

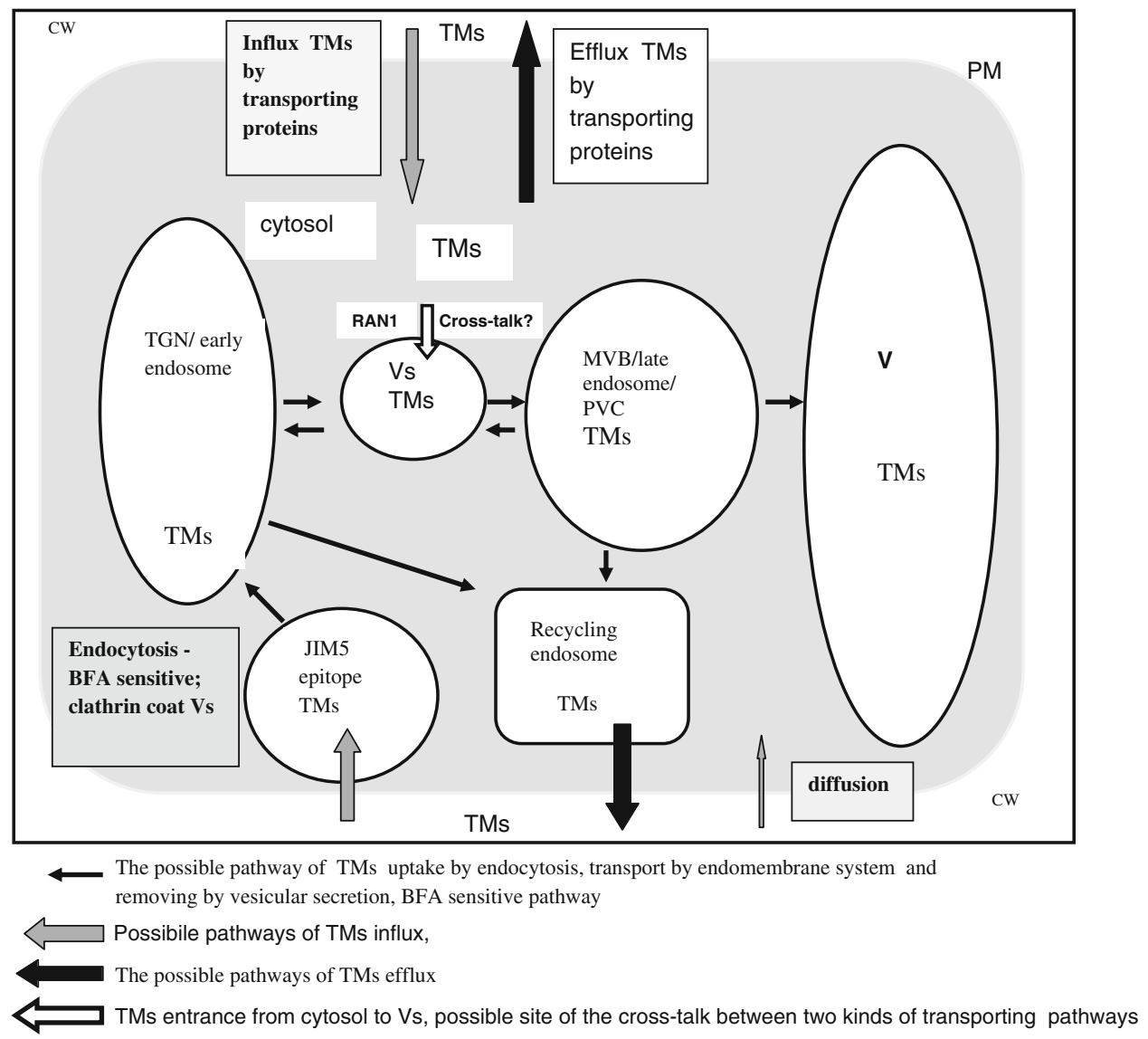


metals from the cytoplasm to the endomembrane system have been detected in A. thaliana recently. They participate in the transport of $\mathrm{Mn}$ and $\mathrm{Ca}$ to TGN and prevacuolar compartments (for review Pilon et al. 2009; Puig and Penarrubia 2009).

The discovery of this phenomenon shows that the cross talk of two TM transport pathways in a plant cell is possible, at least for the essential TMs such as $\mathrm{Cu}$. It is still unknown, however, whether such a transport pathway can function in plant cell toxic metal sequestration strategy and for the transport of non-essential TMs.

Remodeling of polysaccharides and plant cell defense strategy to trace metals

An increase in pectin level in response to TMs was first detected in plants exposed to aluminum, e.g., in roots of Cucurbita maxima (Le Van et al. 1994), Triticum aestivum (Tabuchi and Matsumoto 2001; Hossain et al. 2006), Zea mays (Schmohl and Horst 2000; Schmohl et al. 2000) and Solanum tuberosum (Schmohl et al. 2000). It has been shown that $\mathrm{Al}^{3+}$ causes an increase in the low-methylesterified pectin fraction (Eticha et al. 2005b). It seems likely that this could be the effect of a tolerance mechanism. However, the role of binding $\mathrm{Al}^{3+}$ to low-methylesterified pectins in plant defense strategy is still under discussion. It was found that Al-resistant cultivars of Cynodon dactylon accumulated 33\% more aluminum in CWs than the aluminum-sensitive cultivars (Ramgareeb et al. 2004). On the other hand, most recent studies have shown that an increase in the level of low-methylesterified pectins and binding $\mathrm{Al}^{3+}$ within the $\mathrm{CW}$ are more characteristic of sensitive plant cultivars than those that are tolerant to this metal (Eticha et al. 2005b; Amenós et al. 2009; Tolrá et al. 2009). The reason for this could be that one of the main plant defense strategies is to release $\mathrm{Al}^{3+}$ binding exudates into the rhizosphere. The exudates contain mainly organic acids (for review, e.g., Poschenrieder et al. 2008) and according to recent papers also pectins (Yang et al. 2008). Both compounds bind trivalent metal ions within the rhizosphere, thereby protecting the plant cells from their entry (Poschenrieder et al. 2008; Yang et al. 2008). Moreover, in response to $\mathrm{Al}^{3+}$, plants increase the amount of phenolics, which neutralize oxidative stress and bind the metal ions within the plant (Tolrá et al. 2009). Thus, binding $\mathrm{Al}^{3+}$ within the plant $\mathrm{CW}$ and the increase in the low-methylesterified pectin level do not always appear to be essential for plant tolerance to this metal. In this way, plants might probably minimize the inhibition of cell growth because binding TMs within the $\mathrm{CW}$ and, in particular, its participation in the formation of interaction between HGA molecules result in CW stiffening, which markedly inhibits cell elongation (Eticha et al. 2005b;
Yang et al. 2008). Besides inhibiting meristematic cell divisions, it is one of the main causes of plant growth inhibition observed under TMs stress (Hall 2002; Patra et al. 2004; Poschenrieder et al. 2008).

Nevertheless, it is worth noting that the presence of TMs in the $\mathrm{CW}$ does not always result in $\mathrm{CW}$ stiffening and inhibition of cell elongation. It has been found that the presence of $\mathrm{Cu}$ and $\mathrm{Fe}$ can lead to polysaccharide scission, promoting cell elongation. The mechanism involves generation of $\mathrm{OH}^{-}$in the presence of TMs. Cell wall polysaccharides, such as pectin and xyloglucan, can be broken down by $\mathrm{OH}$ generated in a non-enzymatic Fenton-type reaction, e.g., by the reduction of the $\mathrm{O}_{2}$ with ascorbate in the presence of $\mathrm{Cu}$ ions. Thus, $\mathrm{OH}$ produced in the $\mathrm{CW}$ under TM stress could act as a site-specific oxidant targeted to play a role in the $\mathrm{CW}$ loosening process supporting cell expansion (Fry 1998; Kärkönen and Fry 2006).

It is not clear when the presence of TMs in plant $\mathrm{CW}$ can cause its loosening, and when it causes stiffening. It is possible that the reaction of the $\mathrm{CW}$ could depend on the TM dose and, moreover, on the kind of TM. High doses of TMs can result in the oxidative burst of the ROS. The intensive production of ROS in the apoplast under various stresses can drive the oxidative cross-linking of CW components (Wojtaszek 1997; de Cnodder et al. 2005). The cross-linking of structural proteins as well as of polysaccharides, e.g., pectins (Carpita and Gibeaut 1993) in the CW, has been suggested as a possible mechanism for restricting cell growth (Knox 1995). However, it must be noted that plants have developed different defense mechanisms against various trace metals. As mentioned above for $\mathrm{Al}^{3+}$, it is first of all the immobilization of the toxic ions within the rhizosphere which enables the plant to prevent them from binding within the $\mathrm{CW}$ and which subsequently leads to growth inhibition (Eticha et al. 2005b; Poschenrieder et al. 2008; Yang et al. 2008). For cadmium ions, binding $\mathrm{Cd}^{2+}$ by phytochelatins (small peptides whose synthesis is induced by TM ions; in particular, $\mathrm{Cd}$ in the cytosol), transporting and sequestering in the $\mathrm{V}$, and for $\mathrm{Cu}$ and $\mathrm{Zn}$ chelating by metallothioneins have been well illustrated (for review e.g., Hall 2002; Ernst et al. 2008; Yadav 2009).

Nevertheless, the increase in the amount of pectins, especially low-methylesterified epitopes, could be regarded as a symptom of the defense strategy and plant adaptation to elevated levels of TMs in the soil. Such a point of view lends support to the results of research relating to the defense mechanisms, which function in TM hyperaccumulating plants where the increase in pectin level in response to TMs has been observed. One such example could be the earlier described Scopelophila cataractae, which accumulates the highest amount of $\mathrm{Cu}$ in its $\mathrm{CW}$ pectins. The pectic fraction in $\mathrm{CWs}$ of the $\mathrm{Cu}$-treated material showed that the amount of rhamnose, arabinose and xylose were approximately twofold higher than in the 
control CWs. Moreover, uronic acid was 1.6-fold higher in $\mathrm{Cu}$-treated $\mathrm{CWs}$ than in the control CWs. These data strongly suggested a marked binding of $\mathrm{Cu}$ by pectins in S. cataractae CW (Konno et al. 2010).

A higher polysaccharide level in CWs has also been detected in Allium cepa root cells under $\mathrm{Pb}$ stress (Wierzbicka 1998). Simultaneously, large and numerous $\mathrm{Pb}$ deposits were observed in the $\mathrm{CW}$ of this material. Lead exposition also resulted in an increase in the pectin level in Funaria hygrometrica protonemata. The most striking modification in $\mathrm{CW}$ polysaccharide composition was a substantial increase in low-methylesterified pectins and the formation of $\mathrm{CW}$ thickenings, especially abundant in this pectin epitope (see below). Furthermore, the regions that showed the appearance of low-methylesterified pectin (JIM5-epitope) were related to the distribution and accumulation of $\mathrm{Pb}$ deposits (Fig. $2 \mathrm{~g}$ ). In addition, an increase in de-esterified pectins (PAM1-epitope) was observed. It is worth noting that both pectin epitopes, JIM5 and PAM1, are able to bind divalent metal ions (Krzesłowska et al. 2009a).

A similar reaction involving an increase in the level of low-methylesterified pectins was detected in Linum usitatissimum hypocotyls under Cd stress. Cadmium also caused a reorganization in the distribution of pectin epitopes. It was observed that low-methylesterified pectins (JIM5 epitope) occurred in high amounts within the outer part of the epidermal CW where high methylesterified pectins (JIM7 epitope, generally unable to bind $\mathrm{Cd}^{2+}$ ) virtually disappeared. The authors concluded that the outer region of the $\mathrm{CW}$, rich in low-methylesterified pectins, probably bound $\mathrm{Cd}^{2+}$ and formed a barrier against its penetration. Additionally, it was noted that the amount of cellulose increased (Douchiche et al. 2007).

Further studies concerning L. usitatissimum indicated that $\mathrm{Cd}$ also led to an increase in pectin methylesterase (PME) activity (Paynel et al. 2009). PME, as described above, is the enzyme responsible for the demethylation of high-methylesterified pectins and the formation of low-mehylesterified pectin epitopes (Willats et al. 2006; Pelloux et al. 2007). The higher activity of this enzyme in L. usitatissimum exposed to $\mathrm{Cd}$ resulted in a massive acidification of HGA and the formation of high amounts of low-methylesterified pectin epitopes. Its accumulation was observed in all cell junctions occurring in the cortical tissues, as well as in the most external CW domains of the L. usitatissimum hypocotyl epidermis. The levels of two pectin epitopes increased: low-methylesterified pectins (JIM5 epitope) and an epitope that was able to adopt calcium-induced conformations through its polygalacturonic acid domains (2F4 epitope). Simultaneously, the amount of high methylesterified pectins (JIM7 epitope) decreased in those sites. According to the authors, enhanced JIM5 and 2F4 epitopes in the junctions of the inner tissues might oppose cell separation under Cd stress (Douchiche et al. 2010).

Other reorganizations of $\mathrm{CW}$ polysaccharides occurred in the outer parts of the epidermal tangential $\mathrm{CW}$ of
Fig. 4 Cell wall in plant cell response to TMs: various modifications and remodeling leading to more effective $\mathrm{CW}$ functioning in resistant strategy, a summarizes scheme. The essential and most common of the $\mathrm{CW}$ remodeling strategies in response to trace metals (big arrows)

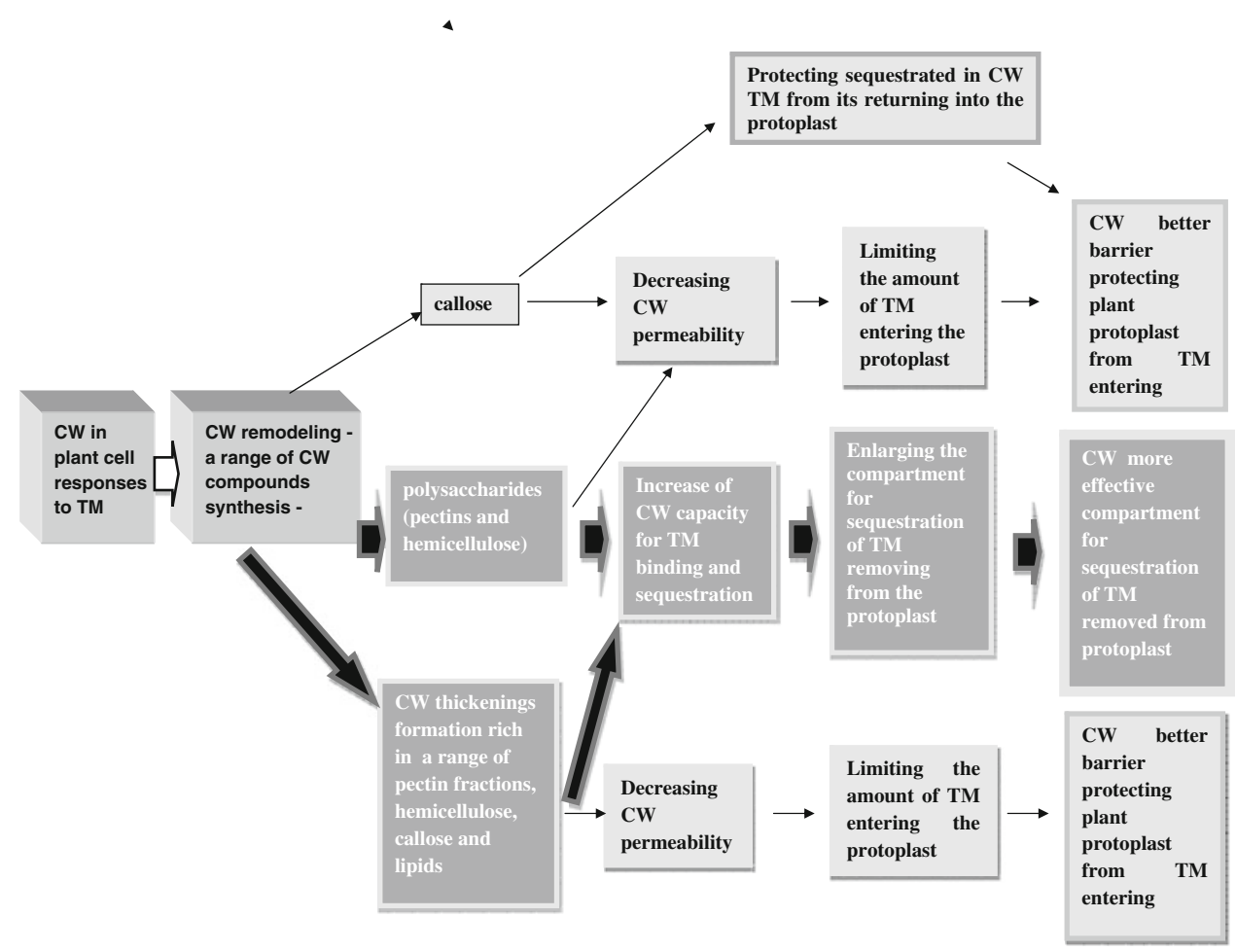


L. usitatissimum hypocotyls. Here, the amount of pectin with non-blockwise pattern of de-esterification (LM7 epitope) significantly increased, compensating for the marked decrease of JIM7 epitope, while JIM5 epitope remained almost constant and the $2 \mathrm{~F} 4$ epitope shifted down. These data again pointed to the possible role of a pectin methylesterase under Cd stress (Paynel et al. 2009) and concluded that the increase of LM7 labeling in the external tangential wall of the epidermis, together with a decrease of JIM7 labeling, suggested a specific role for randomly partially de-esterified pectins in counteracting the radial swelling stress (Douchiche et al. 2010).

Pectins were also observed to increase in Salix viminalis where the main $\mathrm{Cd}$ sink was the $\mathrm{CW}$ of pectin-rich collenchymas (Vollenweider et al. 2006). The amounts of two CW polysaccharides, pectins and hemicelluloses, increased in Oryza sativa exposed to the same metal (Xiong et al. 2009). It must be noted that these effects were triggered by the additional exposition of $O$. sativa to exogenous NO, one of the main stress-signaling molecules (e.g., Wojtaszek 2000; Kopyra and Gwóźdź 2003; Arasimowicz and FloryszakWieczorek 2007). Exogenous NO can increase pectin and hemicellulose levels in root CWs, which enhances $\mathrm{Cd}$ accumulation in root $\mathrm{CWs}$ and subsequently increases rice tolerance to $\mathrm{Cd}$. Furthermore, it was concluded that the CW was a pivotal site of Cd storage in plants (Carrier et al. 2003) and formed the first barrier in blocking the element's penetration of the cells (Xiong et al. 2009). It was demonstrated that about $70-90 \%$ of the $\mathrm{Cd}$ occurring in the rice cells was located in the CWs, which effectively prevented it from entering the cytoplasm (Nishizona et al. 1987). Thus, deposition of $\mathrm{Cd}$ in the $\mathrm{CW}$ was considered to be a crucial mechanism for $\mathrm{Cd}$ tolerance in this plant species. In $O$. $s a$ tiva exposed to $\mathrm{Cd}$, contrary to $L$. usitatissimumm, a decrease of cellulose content was detected (Xiong et al. 2009). This result showed that cellulose was not a key site for $\mathrm{Cd}$ adsorption in rice $\mathrm{CW}$. As the primary structure of cellulose is unbranched, it theoretically should not bind to TMs intensely (Yang et al. 2008).

Modification of $\mathrm{CW}$ composition in response to TMs also occur in the plant roots as a result of interaction with mycorrhizal fungi. In general, the higher tolerance of mycorrhizal plants in comparison to non-mycorrhizal ones is a consequence of TM accumulation by fungal hyphae and protection of root cells from TM penetration (Schützendübel and Polle 2002). However, in O. sativa inoculated with Glomus mosseae under $\mathrm{Cu}$ stress, root $\mathrm{CWs}$ were modified and indicated higher amounts of pectins than those plants which had not been inoculated. Consequently, the roots of mycorrhizal plants accumulated more $\mathrm{Cu}$ in CWs, but much less in the protoplasts compared to nonmycorrhizal ones. This resulted in their higher tolerance to this metal (Zhang et al. 2009).
The results of the studies outlined above have provided evidence that plants, in response to the stress from such metals as $\mathrm{Pb}, \mathrm{Cd}, \mathrm{Cu}$ and $\mathrm{Zn}$, will increase their $\mathrm{CW}$ capacity for TM accumulation by elevating the amount of polysaccharides, especially pectins, which bind TM ions. Hence, in the light of present research, the avoidance of metal ion accumulation in the $\mathrm{CW}$ as described for Al-tolerant plants and the development of other mechanisms as a defense strategy are more of an exception than a rule.

Another modification of $\mathrm{CW}$ polysaccharide composition under TM stress is the appearance of callose (Hall 2002). Callose synthesis is induced by various biotic and abiotic stress factors. It functions as a physical barrier against many stress factors, which may threaten to penetrate the protoplast, e.g., biotic threats such as fungal pathogens (Bolwell et al. 2002), or abiotic threats including wounding (Jacobs et al. 2003) and TM stress (e.g., Hématy et al. 2009). Callose appearance under TM stress has been observed in the response of a range of plant species, e.g., in response to $\mathrm{Pb}$ in Lemna minor (Samardakiewicz et al. 1996) and F. hygrometrica protonemata (Krzesłowska et al. 2009a), and to Al in Triticum aestivum (Sivaguru et al. 2000), A. thaliana (de Cnodder et al. 2005) and Zea mays (Stass et al. 2006). In plants exposed to $\mathrm{Al}$, it has been shown that callose deposition was inducted by the appearance of ROS in the CW and alteration of calcium homeostasis, mainly its increase within protoplast caused by the metal (Sivaguru et al. 2000; Jones et al. 2006). Callose bands deposited in the CW protects the PM and protoplast from TM penetration or at least limits the amount that is able to enter the interior of the cell. For example in $F$. hygrometrica, callose appeared in a $\mathrm{CW}$ thickening at the cell tip, the main entry way of $\mathrm{Pb}$ into the protoplast. It formed a relatively thick layer and undoubtedly blocked metal migration (Krzesłowska et al. 2009a, 2010). Moreover, as described above, callose surrounded large $\mathrm{Pb}$ deposits sequestered in the $\mathrm{CW}$ after its removal from the protoplast and blocked its potential for entering (Krzesłowska et al. 2010). Hence, it was clear that callose which appeared in $F$. hygrometrica protonemata under TM stress played a protective role for the protoplast.

However, in some other plants where callose appeared under TM stress, the protective role was more elusive. In L. minor exposed to $\mathrm{Pb}$, it was found that long bands of callose which could efficiently block TM penetration into the protoplast occurred only in newly formed CWs of roots after cell division and tangential CW. In other CWs callose formed only "patches", which resulted in relatively high penetration of the cell protoplast by $\mathrm{Pb}^{2+}$. Hence, callose in such cells did not form any efficient barrier for preventing $\mathrm{Pb}$ from entering the interior of the cell (Samardakiewicz, personal communication). Moreover, it appeared that under 
TM stress callose was accumulated in plasmodesmata. The accumulation of callose within the plasmodesmata was detected in A. thaliana under Al stress (Sivaguru et al. 2000; de Cnodder et al. 2005) and in L. minor exposed to $\mathrm{Pb}$ (Samardakiewicz, personal communication). In general, callose is a structural component of plasmodesmata (PD), where it can regulate the intercellular exchange of ions and molecules including peptides, hormones, proteins and nucleic acids by changing the size exclusion limit (Roberts and Oparka 2003). However, under TM stress, high amounts of callose, which is deposited in plasmodesmata, inhibits cell-to-cell transport. This results in the prevention of a wide incursion of the toxic metal ions, but it simultaneously inhibits the transport of other molecules, e.g., signaling molecules. In Al-treated plants, deposition of callose in the $\mathrm{CW}$, in particular in the root elongation and differentiation zones, and within the plasmodesmata was related to the inhibition of cell elongation (Sivaguru et al. 2000; de Cnodder et al. 2005; Jones et al. 2006). It was shown that a small quantity of callose appeared in Al-tolerant plants, which resulted in low growth inhibition. Synthesis and appearance of callose were more characteristic for sensitive lines (for review, Poschenrieder et al. 2008).

Thus, as in the case of an increase in pectin level, the appearance of callose in plants exposed to $\mathrm{Al}$ is not regarded as a tolerance strategy to this metal, but rather as a symptom of its sensitivity that results in plant growth inhibition. However, as mentioned above, plants have developed varying efficient defense strategies to this metal besides its accumulation in the $\mathrm{CW}$.

In response to other TMs callose, whether it occurs as a relatively long band or is deposited in sites where TMs enter the cell, as in F. hygrometrica protonemata, it could play a protective role for the protoplast.

\section{Cell wall thickenings}

The results of recent studies concerning the response of plant cells to TMs have provided a great deal of information about thickened $\mathrm{CW}$ and/or local $\mathrm{CW}$ thickening formation. Thickened CWs induced by high metal content have been observed in root cells of Vicia faba growing on mine tailing areas. Those thickenings consisted of two layers: a dense outer one containing numerous, electron dense particles of various size including $\mathrm{Pb}, \mathrm{Zn}$ and $\mathrm{C}$, and an inner less dense layer, containing no electron dense particles. The results suggested that the thickened $\mathrm{CW}$ acts as a barrier limiting metal uptake and penetration into the protoplast in plants exposed to Cd (Probst et al. 2009). A similar role of thickened $\mathrm{CW}$ has been suggested in earlier studies of $V$. faba exposed to $\mathrm{Cd}$ and $\mathrm{Cu}$ (Liu et al. 2004). The barrier role of the thickened $\mathrm{CW}$ was linked to the effect of an increase in peroxidase activity and $\mathrm{CW}$ lignifications (Liu et al. 2004). It is interesting that these cells of $V$. faba, which contained deposits of TMs only in their thickened $\mathrm{CW}$, were not markedly damaged, while highly damaged cells indicated the presence of metal deposits within the protoplast (Probst et al. 2009). Thus, this observation suggests that an increase of the $\mathrm{CW}$ thickness protected plant cells from the toxicity and damaging effects of TMs.

A barrier role of a thickened $\mathrm{CW}$ was also found in $F$. hygrometrica protonemata, a tip growing structure (Schnepf 1982) exposed to Pb (Krzesłowska et al. 2009a, 2010). CW thickenings appeared at the tip of apical cells (Fig. 2d, f), one of the main sites of Pb uptake (Krzesłowska and Woźny 1996). It was striking that the nature of the $F$. hygrometrica thickenings markedly differed from that of the $\mathrm{CW}$ in unexposed plants. As mentioned above, the most important difference was the appearance of high amounts of low-methylesterified pectins (JIM5 epitope Fig. 2f, g) and de-esterified pectins (PAM1epitope) able to bind $\mathrm{Pb}^{2+}$. Both of them were absent in the tip $\mathrm{CW}$ of unexposed protonemata (Fig. 2e) and were generally absent in apical CW of tip growing cells (Li et al. 1994; Stępka et al. 2000). Thus, their appearance under $\mathrm{Pb}$ stress was almost certainly linked with protonema cell defense strategy to this metal. Furthermore, the studies showed that the most extensive part of the CW thickenings was occupied by a granular area absent in the $\mathrm{CW}$ of control plants. This region contained both the highest amount of low-methylesterified pectins and the most numerous, large $\mathrm{Pb}$ deposits (Fig. $2 \mathrm{~g}$ ). In many cases, gold particles, identifying low-methylesterified pectins, appeared to be bound to $\mathrm{Pb}$ deposits. This indicated that this pectin epitope was indeed involved in the immobilisation of high amounts of $\mathrm{Pb}^{2+}$ (Krzesłowska et al. 2009a).

The CW thickenings also contained other compounds, which occurred in the tip CW of control cells such as high methylesterified pectins (JIM7-epitope), RGI with an arabinan side chain (LM6-epitope) and xyloglucan. Moreover, they contained marked amount of callose and two kinds of lipid compounds. Thus, CW thickenings localized at the tip of the apical cell, the main region of $\mathrm{Pb}$ uptake (Krzesłowska and Woźny, 1996) and rich in lowmethylesterified and de-esterified pectins binding $\mathrm{Pb}^{2+}$, callose and lipids, which formed a physical barrier against $\mathrm{Pb}$ migration, functioned as an effective blockade, protecting protonema protoplast from the entering of $\mathrm{Pb}$. Indeed, few $\mathrm{Pb}$ deposits were detected inside the cell (Krzesłowska et al. 2009a).

The formation of $\mathrm{CW}$ thickenings in $F$. hygrometrica protonemata indicating such a different structure and composition to regular $\mathrm{CW}$ in the tip region of the cell required significant $\mathrm{CW}$ remodeling. This was almost certainly due to the increase of the internalization and transport of low-methylesterified pectins and/or PME 
activity and the induction of synthesis of new CW compounds, e.g., callose. Hence, it may be a symptom of a wider defense strategy in plant cells induced by TM stress.

It is worth noting that the addition of $\mathrm{Ca}^{2+}$ to $\mathrm{Pb}$ solution, which can compete in plant cell uptake with $\mathrm{Pb}^{2+}$, resulted in the appearance of markedly smaller $\mathrm{CW}$ thickenings in $F$. hygrometrica protonemata apical cells and the accumulation of $\mathrm{Pb}$ deposits was less numerous (Krzesłowska et al. 2004). Thus, it seems to be possible that the formation of $\mathrm{CW}$ thickenings was closely related to the amount of $\mathrm{Pb}$ entering the cell, and subsequently the level of stress. However, the intercellular signals for CW modifications under TM stress are still elusive. As described above, the intensification of pectins and hemicellulose synthesis could be the effect of the NO signalization pathway in the cell (Xiong et al. 2009). Moreover, recent studies concerning the response of leaves of wheat Yangmai 13 to $\mathrm{Cd}$ have shown that $\mathrm{CW}$ thickening could be due to the effect of ethylene production (Ge et al. 2009). Ethylene plays an important defense role inducing the expression of various defensive genes in response to $\mathrm{Cd}$ stress (O’Donnell et al. 1996). In leaves of wheat Yangmai 13 exposed to $\mathrm{Cd}$, ethylene production resulted in the induction of the UDP-glucose protein transglucosylase (UPTG) enzyme, which plays an important role in synthesizing CW components (Dhugga et al. 1997). According to the authors, it leads to the stimulation of CW thickening formation and increases the $\mathrm{CW}$ capacity for Cd immobilization (Ge et al. 2009).

To sum up, thickened CW limits the amount of TMs penetrating the protoplast, chemically by binding TMs to the negatively charged substances and synthesizing callose and lipid compounds to form physical barriers against ion migration (Fig. 4). In this way, CW thickenings function as a compartment, which is able to accumulate TMs before they can enter the protoplast. On the other hand, thickened $\mathrm{CW}$ can also function as a compartment for the sequestration of TMs removed from protoplast. Hence, both the increase in the size of the CW by the formation of thickening and the synthesis of polysaccharides, such as pectins, increase the CW capacity for TM immobilization. All of these CW modifications significantly enhance the chance of a plant's survival and growth on soils with elevated levels of TMs (Fig. 4).

\section{Concluding remarks}

The results of researches concerning the role of the $\mathrm{CW}$ in plant cell response to TMs evidently show that the $\mathrm{CW}$ is one of the preferential plant cell compartments, which sequestrate TMs. In most plant species, sequestration of toxic TMs within the $\mathrm{CW}$ is a major tolerance strategy, which enables them to survive. The $\mathrm{CW}$ capacity for binding TMs depends on the amount of negatively charged groups of compounds from which it is built. The presence of carboxyl groups is essential for binding divalent and trivalent TM cations in all plants. Such groups are present both in alginate in the $\mathrm{CW}$ of brown algae and in pectins, especially in low-methylesterified fractions, occurring in particularly large amounts in the $\mathrm{CW}$ of mosses and also in the $\mathrm{CW}$ of ferns and flowering plants. Both compound pectins and alginic acid in normal conditions form an eggbox structure by interacting with $\mathrm{Ca}^{2+}$. When plants grow in places that are contaminated by trace metals, $\mathrm{Ca}^{2+}$ is replaced in this interaction by other metal cations such as $\mathrm{Al}, \mathrm{Pb}, \mathrm{Cu}, \mathrm{Cd}$ and $\mathrm{Zn}$, which indicates that they have a higher affinity for these compounds. This mechanism is common to all of the groups of plants described above and is crucial for the sequestration of TMs in plant $\mathrm{CW}$. Therefore, it is not surprising that plant cells increase the capacity of the CW by elevating the level of polysaccharides that bind metal cations and form CWT, which is able to accumulate greater amounts of toxic metal ions and separate them from sensitive sites in the protoplast (Fig. 4). This mechanism, lately detected in numerous plant species, appears to suggest a higher level of tolerance strategy, which allows plants to accumulate more TMs in the apoplast while simultaneously protecting the protoplast from their toxicity. Furthermore, plant cells can additionally prevent TMs deposited in the $\mathrm{CW}$ from returning to the protoplast, e.g., by internalization and combine with $\mathrm{CW}$ compounds, by separating them with the callose layer, as recently detected in moss protonemata (Fig. 2i).

Are plants "wise" or not?

Acknowledgments The author is very grateful to professor Adam Woźny (Laboratory of General Botany, Adam Mickiewicz University Poznań, Poland) for careful reading of the manuscript and fruitful discussions.

Open Access This article is distributed under the terms of the Creative Commons Attribution Noncommercial License which permits any noncommercial use, distribution, and reproduction in any medium, provided the original author(s) and source are credited.

\section{References}

Amenós M, Corrales I, Poschenrieder C, Illeš P, Baluška F, Barcelo J (2009) Different effects of aluminum on the actin cytoskeleton and Brefeldin A-sensitive vesicle recycling in root apex cells of two maize varieties differing in root elongation rate and aluminum tolerance. Plant Cell Physiol 50:528-540

Andres-Colas N, Sancenon V, Rodriguez-Navarro S, Mayo S, Thiele DJ, Ecker JR, Puig S, Penarrubia L (2006) The Arabidopsis heavy metal P-type ATPase HMA5 interacts with metallochaperones and functions in copper detoxification of roots. Plant $\mathrm{J}$ $45: 225-236$ 
Appenroth KJ (2010) What are "heavy metals" in plant sciences? Acta Physiol Plant 32:615-619

Arasimowicz M, Floryszak-Wieczorek J (2007) Nitric oxide as a bioactive signaling molecule in plant stress responses. Plant Sci 172:876-887

Baluška F, Hlavacka A, Šamaj J, Palme K, Robinson D, Matoh T, McCurdy DW, Menzel D, Volkmann D (2002) F-actin-dependent endocytosis of cell wall pectins in meristematic root cells. Insights from brefeldin A-induced compartments. Plant Physiol 130:422-431

Baluška F, Liners F, Hlavacka A, Schlicht M, Van Cutsem P, McCurdy DW, Menzel D (2005) Cell wall pectins and xyloglucans are internalised into dividing root cells and accumulate within cell plates during cytokinesis. Protoplasma 225:141-155

Bolwell GP, Bindschedler LV, Blee KA, Butt VS, Davies DR, Gardner SL, Gerrish C, Minibayeva F (2002) The apoplastic oxidative burst in response to biotic stress in plants: a threecomponent system. J Exp Bot 53:1367-1376

Brooks RR, Lee J, Reeves R, Jaffre T (1977) Detection of nickeliferous rocks by analysis of herbarium specimens of indicator plants. J Geochem Explor 7:49-58

Brunner I, Luster J, Günthardt-Goerg MS, Frey B (2008) Heavy metal accumulation and phytostabilisation potential of tree fine roots in a contaminated soil. Environ Pollut 152:559-568

Caffall KH, Mohnen D (2009) The structure, function, and biosynthesis of plant cell wall pectic polysaccharides. Carbohydr Res 344:1879-1900

Carpita NC, Gibeaut M (1993) Structural models of primary cell walls in flowering plants: consistency of molecular structure with the physical properties of the walls during growth. Plant J 3:1-30

Carrier P, Baryla A, Havaux M (2003) Cadmium distribution and microlocalization in oilseed rape (Brassica napus) after longterm growth on cadmium-contaminated soil. Planta 216:939-950

Chapman VJ (1980) Seaweeds and their uses. Chapman \& Hall, London, pp 334

Colangelo EP, Guerinot ML (2006) Put the metal to the petal: metal uptake and transport throughout plants. Curr Opin Plant Biol 9:322-330

Davis TA, Volesky B, Mucci A (2003) A review of the biochemistry of heavy metal biosorption by brown algae. Water Res 37:4311-4330

de Cnodder T, Vissenberg K, van der Straeten D, Berbelen JP (2005) Regulation of cell length in the Arabidopsis thaliana root by the ethylene precursor 1-aminicyclopropane-1-carboxylic acid: a matter of apoplastic reactions. New Phytol 168:541-550

Delhaize E, Gruber BD, Pittman JK, White RG, Leung H, Miao Y, Jiang L, Ryan PR, Richardson AE (2007) A role for the AtMTP11 gene of Arabidopsis in manganese transport and tolerance. Plant J 51:198-210

Dhugga KS, Tiwari SC, Ray PM (1997) A reversibly glycosylated polypeptide (RGP1) possibly involved in plant cell wall synthesis: purification, gene cloning and trans-golgi localization. Proc Natl Acad Sci USA 94:7679-7684

Douchiche O, Rihouey C, Schaumann A, Driouich A, Morvan C (2007) Cadmium-induced alterations of the structural features of pectins in flax hypocotyl. Planta 225:1301-1312

Douchiche O, Driouich A, Morvan C (2010) Spatial regulation of cell-wall structure in response to heavy metal stress: cadmiuminduced alteration of the methyl-esterification pattern of homogalacturonans. Ann Bot 105:481-491

Dronnet VM, Renard CMGC, Axelos MAV, Thibault JF (1996) Heavy metals binding by pectins: selectivity, quantification and characterization. Carbohydr Polym 30:253-263

Eggert DA (1970) The use of morin for fluorescent localization of aluminum in plant tissues. Stain Technol 45:301-303
Eren E, Argüello JM (2004) Arabidopsis HMA2, a divalent heavy metal transporting $\mathrm{P}(\mathrm{IB})$-type ATPase, is involved in cytoplasmic $\mathrm{Zn}^{2+}$ homeostasis. Plant Physiol 136:3712-3723

Ernst WHO, Verkleij JAC, Schat H (1992) Metal tolerance in plants. Acta Bot Neerl 41:229-248

Ernst WH, Krauss GJ, Verkleij JA, Wesenberg D (2008) Interaction of heavy metals with the sulphur metabolism in angiosperms from an ecological point of view. Plant Cell Environ 31:123-143

Eticha D, Staß A, Horst WJ (2005a) Localization of aluminium in the maize root apex: can morin detect cell wall-bound aluminium? J Exp Bot 56:1351-1357

Eticha D, Stass DA, Horst JW (2005b) Cell-wall pectin and its degree of methylation in the maize root-apex: significance for genotypic differences in aluminium resistance. Plant Cell Environ 28:1410-1420

Fourest E, Volesky B (1996) Contribution of sulphonate groups and alginate to heavy metal biosorption by the dry biomass of Sargassum fluitans. Environ Sci Technol 30:277-282

Fritioff A, Greger M (2003) Aquatic and terrestrial plant species with potential to remove heavy metals from storm water. Int $\mathrm{J}$ Phytoremediat 5:211-224

Fritz E (2007) Measurement of cation exchange capacity (CEC) of plant cell walls by X-ray microanalysis (EDX) in the transmission electron microscope. Microsc Microanal 13:233-244

Fry SC (1998) Oxidative scission of plant cell wall polysaccharides by ascorbate-induced hydroxyl radicals. Biochem J 332:507-515

Ge C, Yan D, Wang Z, Wan D, Wang Y, Shang Q, Luo S (2009) Responses of wheat seedlings to cadmium, mercury and trichlorobenzene stresses. J Environ Sci 21:806-813

Glińska S, Bartczak M, Oleksiak S, Wolska A, Gabara B, Posmyk M, Janas K (2007) Effects of anthocyanin-rich extract from red cabbage leaves on meristematic cells of Allium cepa L. roots treated with heavy metals. Ecotoxicol Environ Saf 68:343-350

Grant GT, Morris ER, Rees DA, Smith PJC, Thom D (1973) Biological interactions between polysaccharides and divalent cations: the "egg-box" model. FEBS Lett 32:195-198

Hall LJ (2002) Cellular mechanism for heavy metal detoxification and tolerance. J Exp Bot 53:1-11

Hématy K, Cherk C, Somerville S (2009) Host-pathogen warfare at the plant cell wall. Curr Opin Plant Biol 12:406-413

Hossain AKMZ, Koyama H, Hara T (2006) Growth and cell wall properties of two wheat cultivars differing in their sensitivity to aluminium stress. J Plant Physiol 163:39-47

Hubner RH, Depta H, Robinson DG (1985) Endocytosis in maize root cap cells. Evidence obtain using heavy metal salt solution. Protoplasma 129:214-222

Illéš P, Schlicht M, Pavlovkin J, Lichtscheidl I, Baluška F, Ovečka M (2006) Aluminium toxicity in plants: internalization of aluminium into cells of the transition zone in Arabidopsis root apices related to changes in plasma membrane potential, endosomal behavior, and nitric oxide production. J Exp Bot 57:4201-4213

Islam E, Yang X, Li T, Liu D, Jin X, Meng F (2007) Effect of Pb toxicity on root morphology, physiology and ultrastructure in the two ecotypes of Elsholtzia argyi. J Hazard Mater 147:806-816

Jacobs AK, Lipka V, Burton RA, Panstruga R, Strizhov SchulzeLefert P, Fincher GB (2003) An Arabidopsis callose synthase, GSL5, is required for wound and papillary callose formation. Plant Cell 15:2503-2513

Jiang X, Wang C (2008) Zinc distribution and zinc-binding forms in Phragmites australis under zinc pollution. J Plant Physiol 165:697-704

Jones DL, Blancaflor EB, Kochian LV, Gilroy S (2006) Spatial coordination of aluminum uptake, production of reactive oxygen species, callose production and wall rigidification in maize roots. Plant Cell Environ 29:1309-1318 
Kähkönen MA, Pantsar-Kallio M, Manninen PKG (1997) Analysing heavy metal concentrations in the different parts of Elodea canadensis and surface sediment with PCA in two different boreal lake in southern Finland. Chemosphere 35:2645-2656

Kartel MT, Kupchik LA, Veisov BK (1999) Evaluation of pectin binding of heavy metal ions in aqueous solutions. Chemosphere 38:2591-2596

Kärkönen A, Fry SC (2006) Effect of ascorbate and its oxidation products on $\mathrm{H}_{2} \mathrm{O}_{2}$ production in cell-suspension cultures of Picea abies and in the absence of cells. J Exp Bot 57:1633-1644

Kim D, Gustin JL, Lahner B, Persans MW, Baek D, Yun DJ, Salt DE (2004) The plant CDF family member TgMTP1 from the Ni/Zn hyperaccumulator Thlaspi goesingense acts to enhance efflux of $\mathrm{Zn}$ at the plasma membrane when expressed in Saccharomyces cerevisiae. Plant J 39:237-251

Kim D-Y, Bovet L, Maeshima M, Martinoia E, Lee Y (2007) The ABC transporter AtPDR8 is a cadmium extrusion pump conferring heavy metal resistance. Plant J 50:207-218

Knox JP (1995) The extracellular matrix in higher plants. Developmentally regulated proteoglycans and glycoproteins of the plant cell surface. FASEB J 9:1004-1012

Konno H, Nakato T, Nakashima S, Katoh K (2005) Lygodium japonicum fern accumulates copper in the cell wall pectin. J Exp Bot 56:1923-1931

Konno H, Nakashima S, Katoh K (2010) Metal-tolerant Scopelophila cataractae moss accumulates copper in the cell wall pectin of protonemata under copper-enriched conditions. J Plant Physiol 167:358-364

Kopittke PM, Asher CJ, Kopittke RA, Menzies NW (2007) Toxic effects of $\mathrm{Pb}^{2+}$ on growth of cowpea (Vigna unguiculata). Environ Pollut 150:280-287

Kopittke PM, Asher CJ, Blamey FP, Auchterlonie GJ, Guo YN, Menzies NW (2008) Localization and chemical speciation of $\mathrm{Pb}$ in roots of signal grass (Brachiaria decumbens) and Rhodes grass (Chloris gayana). Environ Sci Technol 42:4595-4599

Kopyra M, Gwóźdź EA (2003) Nitric oxide stimulates seed germination and counteracts the inhibitory effect of heavy metals and salinity on root growth of Lupinus luteus. Plant Physiol Biochem 41:1011-1017

Krämer U, Talke IN, Hanikenne M (2007) Transition metal transport. FEBS Lett 581:2263-2272

Krzesłowska M, Woźny A (1996) Lead uptake localization and changes in cell ultrastructure of Funaria hygrometrica protonemata. Biol Plant 38:253-259

Krzesłowska M, Woźny A, Konieczna-Koperska J (2004) Calcium ameliorates effects of lead in protonema of Funaria hygrometrica. Hedw Biol Plant 48:569-574

Krzesłowska M, Lenartowska M, Mellerowicz EJ, Samardakiewicz S, Woźny A (2009a) Pectinous cell wall thickenings formation-a response of moss protonemata cells to $\mathrm{Pb}$. Environ Exp Bot 65:119-131

Krzesłowska M, Samardakiewicz S, Woźny A (2009b) Cell wall in the plant cell response to trace metals. Metal transport and sequestration. In: Maksymiec W (ed) Compartmentation of responses to stresses in higher plants, true or false. Transworld Research Network, Kerala, India, pp 19-60 (in press)

Krzesłowska M, Lenartowska M, Samardakiewicz S, Bilski H, Woźny A (2010) Lead deposited in the cell wall of Funaria hygrometrica protonemata is not stable-a remobilization can occur. Environ Pollut 158:325-338

Książek M, Woźny A, Siwecki R (1984) The sensitivity of poplar leaves to $\mathrm{Pb}$ nitrate and the intracellular localization of $\mathrm{Pb}$. Eur $\mathrm{J}$ For Pathol 14:113-122

Le Van H, Kuraishi S, Sakurai N (1994) Aluminium-induced rapid root inhibition and changes in cell-wall components of squash seedlings. Plant Physiol 106:971-976
Lee M, Lee K, Lee J, Noh EW, Lee Y (2005) AtPDR12 contributes to lead resistance in Arabidopsis. Plant Physiol 138:827-836

Levitt J (1980) Response of plants to environmental stresses, vol 2, 2nd edn. Academic Press, New York

Levy S, Staehelin LA (1992) Synthesis, assembly and function of plant cell wall macromolecules. Curr Opin Cell Biol 4:856-862

Li Y-Q, Chen F, Linskens H, Cresti M (1994) Distribution of unesterified and esterified pectins in cell walls of pollen tubes of flowering plants. Sex Plant Rep 7:145-152

Liu HY, Liao BH, Lu SQ (2004) Toxicity of surfactant, acid rain and $\mathrm{Cd}^{2+}$ combined pollution to the nucleus of Vicia faba root tip cells. Chin J App Ecol 15:493-496

Lozanno-Álvarez JA, Jáuregui-Rincón J, Méndoza-Diaz G, Rodríguez-Vázcuez R, Frausto-Reyes C (2009) Study of sorption equilibrium of biopolymers alginic acid and xantan with C.I. disperse yellow 54. J Mex Chem Soc 53:59-70

Lütz-Meindl U (2007) Use of energy filtering transmission electron microscopy for image generation and element analysis in plant organisms. Micron 38:181-196

Malone C, Koppe DE, Miller RJ (1974) Localization of $\mathrm{Pb}$ accumulated by corn plants. Plant Physiol 53:388-394

Małecka A, Piechalak A, Morkunas I, Tomaszewska B (2008) Accumulation of lead in root cells of Pisum sativum. Acta Physiol Plant 30:629-637

Meyers DE, Kopittke PM, Auchterlonie GJ, Webb RI (2009) Characterization of lead precipitate following uptake by roots of Brassica juncea. Environ Toxicol Chem 28:250-255

Mills RF, Francini A, Ferreira da Rocha PS, Baccarini PJ, Aylett M, Krijger GC, Williams LE (2005) The plant P1B-type ATPase AtHMA4 transports $\mathrm{Zn}$ and $\mathrm{Cd}$ and plays a role in detoxification of transition metals supplied at elevated levels. FEBS Lett 579:783-791

Milner MJ, Kochian LV (2008) Investigating heavy-metal hyperaccumulation using Thlaspi caerulescens as a model system. Ann Bot 102:3-13

Neumann D, zur Nieden U (2001) Silicon and heavy metal tolerance in higher plants. Phytochem 56:685-692

Nishizona H, Zchikawa H, Suzuki S, Ishii F (1987) The role of the root cell wall in heavy metal tolerance of Athyrium yokosense. Plant Soil 101:15-20

Nyquist J, Greger M (2007) Uptake of $\mathrm{Zn}, \mathrm{Cu}$, and Cd in metal loaded Elodea canadensis. Environ Exp Bot 60:219-226

O’Donnell PJ, Calvert C, Atzorn R, Wasternack C, Leyser HMO, Bowles DJ (1996) Ethylene as a signal mediating the wound response of tomato plants. Science 274:1914-1917

Otegui MS, Spitzer Ch (2008) Endosomal functions in plants. Traffic 9:1589-1598

Ovečka M, Lang I, Baluška F, Ismail A, Illeš P, Lichtscheid K (2005) Endocytosis and vesicle trafficking during tip growth of root hairs. Protoplasma 226:39-54

Patra M, Bhowmik N, Bandopadhyay B, Sharma A (2004) Comparison of mercury, lead and arsenic with respect to genotoxic effects on plant systems and the development of genetic tolerance. Environ Exp Bot 52:199-223

Pawlak S, Deckert J (2007) Histone modifications under environmental stress. Biol Lett 44:53-61

Paynel F, Schaumann A, Arkoun M, Douchiche O, Morvan C (2009) Temporal regulation of cell-wall pectin methylesterase and peroxidase isoforms in cadmium-treated flax hypocotyl. Ann Bot 104:1363-1372

Pelloux J, Rustérucci C, Mellerowicz EJ (2007) New insight into pectin methylesterase structure and function. Trends Plant Sci 12:267-277

Pilon M, Cohu CM, Ravet K, Abdel-Ghany SE, Gaymard F (2009) Essential transition metal homeostasis in plants. Curr Opin Plant Biol 12:347-357 
Połeć-Pawlak K, Ruzik R, Lipiec E, Ciurzyńska M, Gawrońska H (2007) Investigation of $\mathrm{Pb}(\mathrm{II})$ binding to pectin in Arabidopsis thaliana. J Anal At Spectrom 22:968-972

Poschenrieder C, Gunsé B, Corrales I, Barceló J (2008) A glance into aluminium toxicity and resistance in plants. Sci Total Environ 400:356-368

Prasad MNV (ed) (2004) Heavy metal stress in plant: from molecules to ecosystems. Springer, Heidelberg

Probst A, Liu H, Fanjul M, Liao B, Hollande E (2009) Response of Vicia faba L. to metal toxicity on mine tailing substrate: geochemical and morphological changes in leaf and root. Environ Exp Bot 66:297-308

Przymusiński R, Rucińska-Sobkowiak R, Ilska B, Gwóźdź EA (2007) Organospecific responses of lupin seedlings to lead. Localization of hydrogen peroxide and peroxidase activity. Acta Physiol Plant 29:411-416

Puig S, Penarrubia L (2009) Placing metal micronutrients in context: transport and distribution in plants. Curr Opin Plant Biol 12:299-306

Ramgareeb S, Cooke JA, Watt MP (2004) Responses of meristematic callus cells of two Cynodon dactylon genotypes to aluminium. J Plant Physiol 161:1245-1258

Renard CMGC, Jarvis MC (1999) Acetylation and methylation of homogalacturonans. 2: effect on ion-binding properties and conformations. Carbohydr Polym 39:209-216

Roberts AG, Oparka KJ (2003) Plasmodesmata and the control of symplastic transport. Plant Cell Environ 26:103-124

Rucińska-Sobkowiak R, Pukacki S (2006) Antioxidactive defence system in lupin roots exposed to increasing concentrations of lead. Acta Physiol Plant 28:357-364

Salt DE, Prince RC, Baker AJM, Pikering IJ (1999) Zinc ligands in the metal hyperaccumulator Thlaspi caerulescens as determined using X-ray absorption spectroscopy. Environ Sci Technol 33:713-717

Šamaj J, Baluška F, Voigt B, Schlicht M, Volkmann D, Menzel D (2004) Endocytosis, actin cytoskeleton, and signaling. Plant Physiol 135:1104-1161

Samardakiewicz S, Strawiński P, Woźny A (1996) The influence of lead on callose formation in roots of Lemna minor L. Biol Plant 38:463-467

Samardakiewicz S, Woźny A (2000) The distribution of $\mathrm{Pb}$ in duckweed (Lemna minor L.) root tip. Plant Soil 226:107-111

Schmohl N, Horst WJ (2000) Cell wall pectin content modulates aluminium sensitivity of Zea mays (L.) cell grown in suspension culture. Plant Cell Environ 23:735-742

Schmohl N, Pilling J, Fisahn J, Horst WJ (2000) Pectin methylesterase modulates aluminium sensitivity in Zea mays and Solanum tuberosum. Physiol Plant 109:419-427

Schnepf E (1982) Morphogenesis in moss protonema. In: Loyd CW (ed) The cytoskeleton in plant growth and development. Academic Press, New York, pp 321-344

Schützendübel A, Polle A (2002) Plant responses to abiotic stresses: heavy metal-induced oxidative stress and protection by mycorrhization. J Exp Bot 53:1351-1365

Schwarzerová K, Zelenková S, Nick P, Opatrny Z (2002) Aluminuminduced rapid changes in the microtubular cytoskeleton of tobacco cell lines. Plant Cell Physiol 43:207-216

Sela M, Tel-Or E, Fritz E, Huttermann A (1988) Localization and toxic effects of cadmium, copper, and uranium in Azolla. Plant Physiol 88:30-36

Silva IR, Smyth TJ, Moxley DF, Carter TE, Allen AS, Rufty TW (2000) Aluminium accumulation at nuclei of cells in the root tip. Fluorescence detection using lumogallion and confocal laser scanning microscopy. Plant Physiol 123:543-552

Sivaguru M, Fujiwara T, Šamaj J, Baluška F, Yang ZM, Osawa H, Maeda T, Mori T, Volkmann D, Matsumoto H (2000)
Aluminium-induced $1 \rightarrow 3$ - $\beta$-D-glucan inhibits cell-to-cell trafficking of molecules through plasmodesmata. A new mechanism of aluminium toxicity in plants. Plant Physiol 124:991-1005

Stass A, Wang Y, Eticha D, Horst WJ (2006) Aluminium rhizotoxicity in maize grown in solutions with $\mathrm{Al}^{3+}$ or $\mathrm{Al}(\mathrm{OH})^{-4}$ as predominant solution Al species. J Exp Bot 15:4033-4042

Stępka M, Ciampolini F, Charzyńska M, Cresti M (2000) Localization of pectins in the pollen tube wall of Ornithogalum virens. Does the pattern of pectin distribution depend on the growth rate of the pollen tube? Planta 210:630-635

Tabuchi A, Matsumoto H (2001) Changes in cell-wall properties of wheat (Triticum aestivum) roots during aluminium induced growth inhibition. Physiol Plant 112:353-358

Tolrá R, Barcelo J, Poschenrieder CH (2009) Constitutive and aluminium-induced patterns of phenolic compounds in two maize varieties differing in aluminium tolerance. J Inorg Biochem 103:1486-1490

Tung G, Temple PJ (1996) Histochemical detection of lead in plant tissues. Environ Toxicol Chem 15:906-914

Turnau K, Henriques FS, Anielska T, Renker C, Buscot F (2007) Metal uptake and detoxification mechanisms in Erica andevalensis growing in a pyrite mine tailing. Environ Exp Bot 61:117-123

Tyler G (1990) Bryophytes and heavy metals: a literature review. Bot J Linn Soc 104:231-253

Vida TA, Emr SD (1995) A new vital stain for visualizing vacuolar membrane dynamics and endocytosis in yeast. $\mathrm{J}$ Cell Biol 128:779-792

Vogel-Mikuš K, Simič J, Pelicon P, Budnar M, Kump P, Nečember M, Mesjasz-Przybyłowicz J, Przybyłowicz WJ, Regvar M (2008) Comparison of essential and non-essential element distribution in leaves of the $\mathrm{Cd} / \mathrm{Zn}$ hyperaccumulator Thlaspi praecox as revealed by micro-PIXE. Plant Cell Environ 31:1484-1496

Vollenweider P, Cosio C, Günthardt-Goerg MS, Keller C (2006) Localization and effects of cadmium in leaves of a cadmiumtolerant willow (Salix viminalis L.). Part II Microlocalization and cellular effects of cadmium. Environ Exp Bot 58:25-40

Wierzbicka M (1998) Lead in the apoplast of Allium cepa L. root tips: ultrastructural studies. Plant Sci 133:105-119

Wierzbicka MH, Przedpełska E, Ruzik R, Ouerdane L, Połeć-Pawlak K, Jarosz M, Szpunar J, Szakiel A (2007) Comparison of the toxicity and distribution of cadmium and $\mathrm{Pb}$ in plant cells. Protoplasma 231:99-111

Willats WGT, Knox JP, Mikkelsen JD (2006) Pectin: new insights into an old polymer are starting to gel. Trends Food Sci Technol 17:97-104

Williams LE, Mills RF (2005) P1B-ATPases—an ancient family of transition metal pumps with diverse functions in plants. Trends Plant Sci 10:149-502

Williams LE, Pittman JK, Hall JL (2000) Emerging mechanisms for metal transport in plant. Biochem Biophys Acta 1465:104-126

Woeste KE, Kieber JJ (2000) A strong loss-of-function mutation in RAN1 results in constitutive activation of ethylene response pathway as well as a rosette-lethal phenotype. Plant Cell $12: 443-455$

Wojas S, Hennig J, Plaza S, Geisler M, Siemianowski O, Skłodowska A, Ruszczyńska A, Bulska E, Antosiewicz DM (2009) Ectopic expression of Arabidopsis ABC transporter MRP7 modifies cadmium root-to-shoot transport and accumulation. Environ Pollut 157:2781-2789. doi:10.1016/j.envpol.2009.04.024

Wójcik M, Vangronsveld J, D’Haen J, Tukiendorf A (2005) Cadmium tolerance in Thlaspi caerulescens. II. Localization of cadmium in Thlaspi caerulescens. Env Exp Bot 53:163-171

Wojtaszek P (1997) Oxidative burst: an early plant response to pathogen infection. Biochem J 322:681-692

Wojtaszek P (2000) Nitric oxide in plants. To NO or not to NO. Phytochemistry 54:1-4 
Woźny A, Zatorska B, Młodzianowski F (1982) Influence of $\mathrm{Pb}$ on the development of lupin seedlings and ultrastructural localization of this metal in the roots. Acta Soc Bot Pol 5:345-351

Xiong J, An L, Lu H, Zhu C (2009) Exogenous nitric oxide enhances cadmium tolerance of rice by increasing pectin and hemicellulose contents in root cell wall. Planta 230:755-765

Yadav SK (2009) Heavy metals toxicity in plants: an overview on the role of glutathione and phytochelatins in heavy metal stress tolerance of plants. S Afr J Bot. doi:10.1016/j.sajb.2009.10.007

Yang X, Feng Y, He Z, Stoffella PJ (2005) Molecular mechanisms of heavy metal hyperaccumulation and phytoremediation. J Trace Elem Med Biol 18:339-353
Yang JL, Li YY, Zhang YJ, Zhang SS, Wu YR, Wu P, Zheng SJ (2008) Cell wall polysaccharides are specifically involved in the exclusion of aluminium from the rice root apex. Physiol Plant 146:602-611

Zhang XH, Lin AJ, Gao YL, Reid RJ, Wong MH, Zhu YG (2009) Arbuscular mycorrhizal colonisation increases copper binding capacity of root cell walls of Oryza sativa L. and reduces copper uptake. Soil Biol Biochem 41:930-935

Zonia L, Munnik T (2008) Vesicle trafficking dynamics and visualization of zones of exocytosis and endocytosis in tobacco pollen tubes. J Exp Bot 59:861-873 